INTER NATIONAL MONETARY FUND
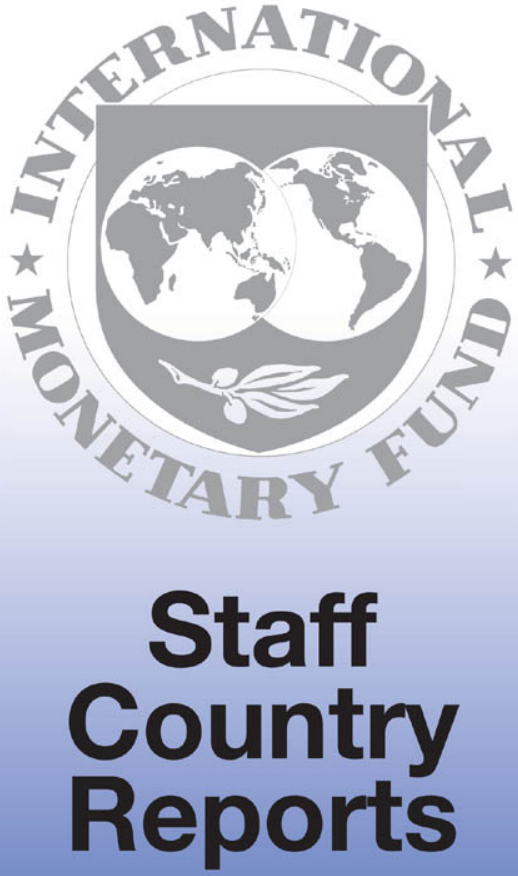


\section{Kuwait: 2006 Article IV Consultation-Staff Report; Staff Statement; Public Information Notice on the Executive Board Discussion; and Statement by the Executive Director for Kuwait}

Under Article IV of the IMF's Articles of Agreement, the IMF holds bilateral discussions with members, usually every year. In the context of the 2006 Article IV consultation with Kuwait, the following documents have been released and are included in this package:

- the staff report for the 2006 Article IV consultation, prepared by a staff team of the IMF, following discussions that ended on December 14, 2005, with the officials of Kuwait on economic developments and policies. Based on information available at the time of these discussions, the staff report was completed on February 21, 2005. The views expressed in the staff report are those of the staff team and do not necessarily reflect the views of the Executive Board of the IMF.

- $\quad$ a staff statement of March 8, 2006 updating information on recent developments.

- $\quad$ a Public Information Notice (PIN) summarizing the views of the Executive Board as expressed during its March 10, 2006 discussion of the staff report that concluded the Article IV consultation.

- $\quad$ a statement by the Executive Director for Kuwait.

The documentlisted below has been or will be separately released.

\section{Statistical Appendix}

The policy of publication of staff reports and other documents allows for the deletion of market-sensitive information.

To assist the IMF in evaluating the publication policy, reader comments are invited and may be sent by e-mail to publicationpolicy@imf.org.

Copies of this report are available to the public from

International Monetary Fund • Publication Services

$70019^{\text {th }}$ Street, N.W. • Washington, D.C. 20431

Telephone: (202) 623-7430 • Telefax: (202) 623-7201

E-mail: publications@imf.org • Internet: http://www.imf.org

Price: $\$ 15.00$ a copy

\section{International Monetary Fund Washington, D.C.}


This page intentionally left blank

(CInternational Monetary Fund. Not for Redistribution 
INTERNATIONAL MONETARY FUND

\section{KUWAIT}

\section{Staff Report for 2006 Article IV Consultation}

Prepared by Staff Representatives for the 2006 Consultation with Kuwait

Approved by Lorenzo Pérez and Juha Kähkönen

February 21, 2006

- The 2006 Article IV consultation discussions were held in Kuwait from November 30 to December 14, 2005.

- $\quad$ The team comprised Messrs. Mansur (head), Delgado, Floerkemeier, and Govil, and Ms. Farahbaksh (all MCD). Mr. Shaalan, Executive Director for Kuwait, also participated in the policy discussions.

- $\quad$ The mission met with Mr. Bader Mishary Al-Humaidhi, Minister of Finance; Mr. Abdullah Abdul Rahman Al-Taweel, Minister of Commerce; Sheikh Salem Abdulaziz Al-Sabah, Governor, Central Bank of Kuwait (CBK); Dr. Nabeel Al-Mannae (Deputy Governor, CBK); and other representatives from the government and private sectors.

- The previous consultation was concluded on April 25, 2005. The Public Information Notice of the Executive Board's discussion is available at http://www.imf.org/external/np/sec/pn/2005/pn0563.htm.

- $\quad$ Kuwait accepted the obligations of Article VIII on April 5, 1963, and maintains an exchange system free of restrictions on the making of payments and transfers for current international transactions.

- $\quad$ Kuwait's currency is pegged to the U.S. dollar at a fixed exchange rate of KD 0.299 per U.S. dollar since January 2003.

- $\quad$ The authorities will consider issuing the Public Information Notice (PIN) and publishing the staff report following the conclusion of the Article IV consultation discussion by the Executive Board. 


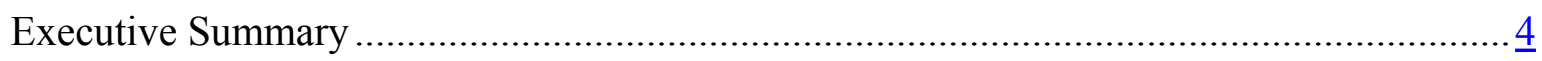

I. Background and Recent Developments................................................................. $\frac{5}{5}$

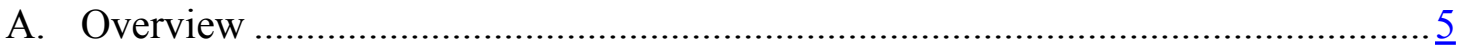

B. Recent Macroeconomic Developments and Structural

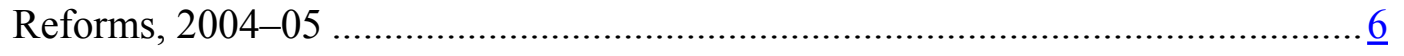

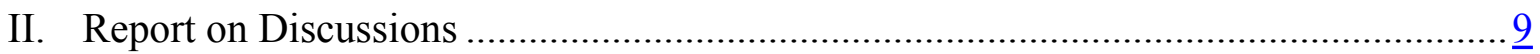

A. Near- and Medium-Term Outlook Remains Strong ............................................ 10

B. Hydrocarbon Sector: Is the Investment Plan Supportive of Global Oil Market Stability and Kuwait's Growth Potential? ...............................11

C. Fiscal policy: Improving Resource Management and Ensuring Long-Term Fiscal Viability ............................................................................

D. Monetary and Financial Sector Policies: Promoting Financial Intermediation While Safeguarding Macroeconomic Stability …………………... 16

E. Structural Reform: How can Kuwait Sustain Its Non-Oil Growth Momentum? .................................................................................

F. Statistical and Other Issues...........................................................................

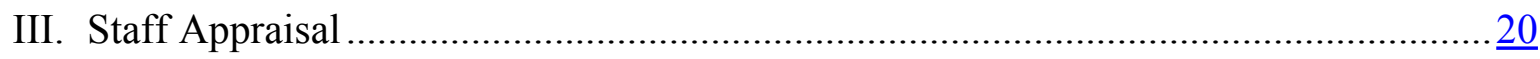

\section{Text Boxes}

1. Kuwait Stock Market: Recent Developments and Some Characteristics....................... 7

2. Hydrocarbon Sector Investment Plans, 2006-11 ................................................. $\frac{12}{12}$

3. Kuwait: How Should the Fiscal Surpluses be Used? …………................................ 15

Figures

GCC: Oil GDP as percent of total GDP.....................................................................

Domestic Investment in Selected GCC Countries, 2000-05 ............................................. $\frac{5}{6}$

GDP Growth and Inflation, 2000-05 ...................................................................... $\frac{6}{6}$

GCC Government Saving, 2004 .................................................................................

Exchange Rate Movements, January 1990-November 2005 …………............................... $\frac{8}{8}$

Broad Money and Credit to Nongovernment Sector, 2000-05 .......................................... $\frac{8}{2}$

Fiscal and Current Account Surpluses, 2000-10 ………................................................. 10

Fiscal and External Current Account Outlook Under Alternative Oil

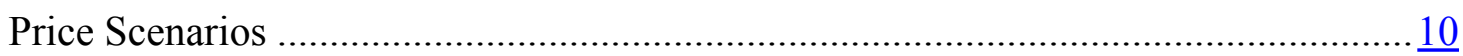

Oil Production Increase, 2003-05 .......................................................................

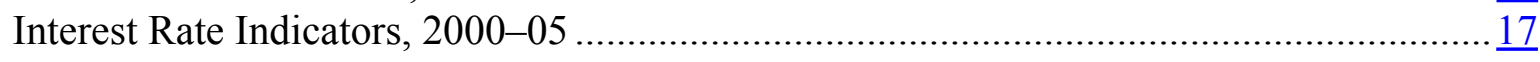


Text Tables

Kuwait Fund for Arab Economic Development, 2004/05

Tables

1. Selected Economic Indicators, 2001-06 23

2. Summary of Government Finance, 2001/02-2010/11 .......................................... $\frac{25}{26}$

3. Summary of Balance of Payments, 2002-10 ....................................................... $\frac{26}{27}$

4. Monetary Survey, 2000-06 ….......................................................................... 27

5. Selected Economic Indicators and Illustrative Baseline Scenario, 2001-10 ............. $\underline{28}$

6. Financial Soundness and Other Vulnerability Indicators, 2001-05 ........................29

Appendixes

I. Fund Relations ......................................................................................... $\frac{31}{33}$

II. Relations with the World Bank......................................................................... $\frac{33}{35}$

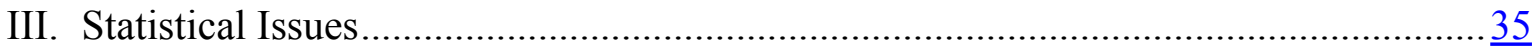




\section{EXECUTIVE SUMMARY}

\section{Current setting}

Kuwait's macroeconomic performance has been strong in recent years reflecting sharply higher oil and non-oil activity. Real GDP growth was strong (averaging 7.5 percent during 2004-05); inflation remained low; and the external current account and fiscal surpluses increased sharply. The stock price index has more than tripled during the period 2003-05, including a 67 percent increase in 2005 .

Over the medium term, Kuwait's financial position is projected to remain strong. The large external current account and fiscal surpluses are expected to lead to a buildup of a large stock of financial assets for future generations. However, GDP growth is expected to slow down unless the pace of structural reforms accelerates. There are also downside risks to this favorable medium-term financial outlook since it is based on historically high levels of oil price and output assumptions.

\section{Policy discussions}

- $\quad$ Kuwait continued to play a constructive role in support of oil price stability. In response to growing world demand, oil production has increased significantly, and a $\$ 22$ billion plan to expand crude oil capacity to $3 \mathrm{mbd}$ by 2008 , increase refining capacity, and almost double the production of petrochemical products is being implemented.

- $\quad$ Although the overall fiscal position is projected to remain in a comfortable surplus over the medium term, the staff encouraged the authorities to consider improvements in the structure of the budget by gradually increasing capital expenditure, rationalizing transfers and subsidies, and achieving a better balance between productive expenditure and fiscal saving. Managing the rapidly growing savings fund for future generations effectively will also be key to Kuwait's long-term fiscal viability.

- $\quad$ Monetary policy has been successful in maintaining price stability and the exchange rate peg. The Kuwaiti banking system continues to be financially sound, wellmanaged and effectively supervised. The continuing upward trend in the stock price index, despite strong economic fundamentals, poses some risk to the otherwise favorable financial sector outlook. Staff urged the authorities to expeditiously legislate a capital market authority law to intensify oversight of the stock market.

- $\quad$ Progress on the structural reform front remains slow. The authorities have adopted some measures to allow for a broader role of the private sector in the economy, but the reforms need to be cast in the context of a comprehensive strategy. 


\section{BACKGROUND AND RECENT DEVELOPMENTS}

\section{A. Overview ${ }^{1}$}

1. The consultation discussions were held against a backdrop of strong economic activity, high oil prices and large fiscal and external surpluses, but slow progress in the implementation of structural reforms. The optimism created by high oil prices and output has resulted in booming non-oil activity, a rapidly expanding equity market, and building up of assets for future generations at an accelerated pace, in conjunction with increased allocations for higher public spending. ${ }^{2}$

2. The authorities' stated objectives are to achieve a sustainable high rate of nonoil GDP growth to diversify the economy ${ }^{3}$ and absorb the fast growing Kuwaiti labor force; ensure intergenerational equity through an accelerated buildup of assets; and guard against potential instability arising from the asset market. In the previous Article IV consultations, the staff made recommendations to speed up structural reforms, and strengthen the budget structure and oversight of the financial sector.
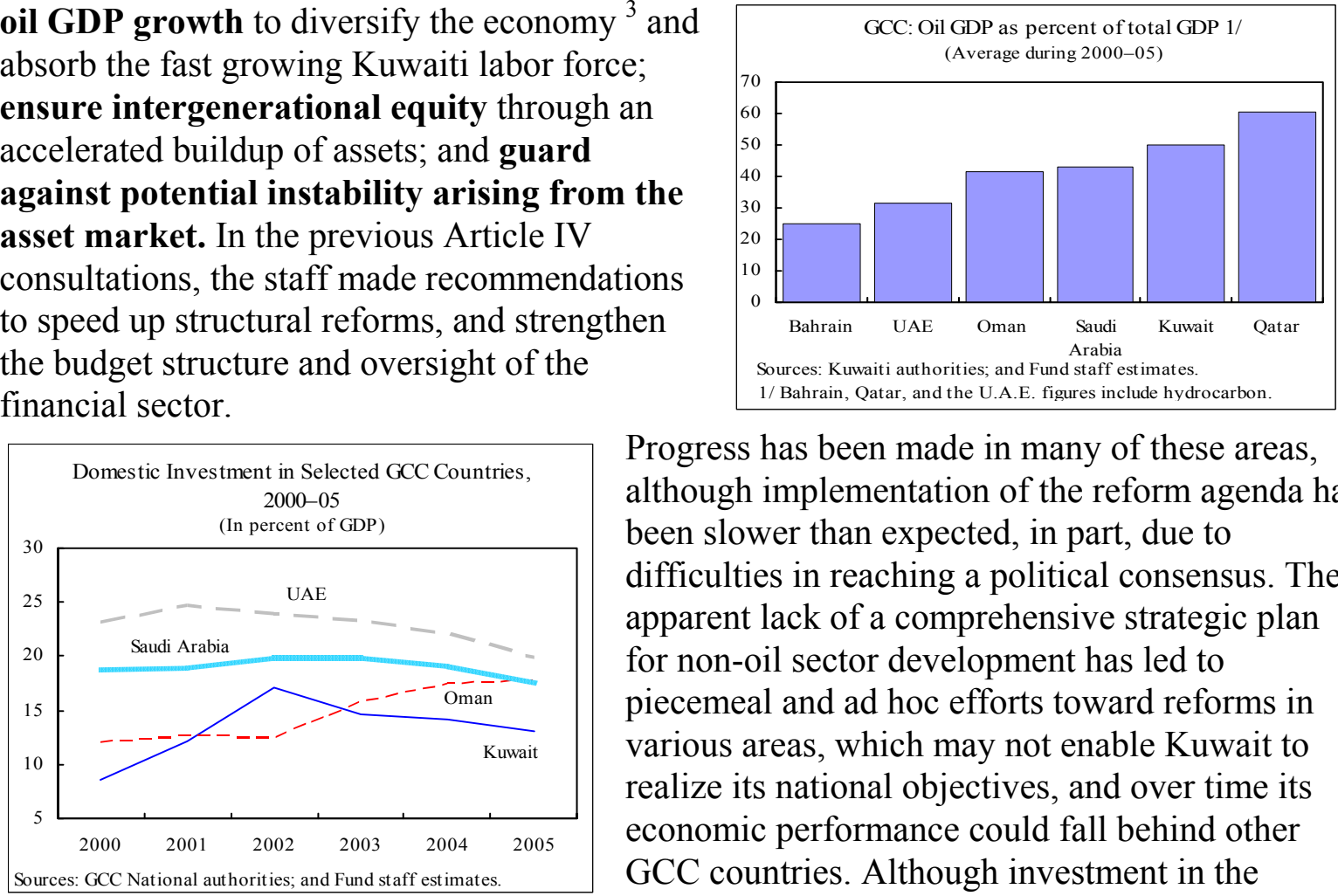

Progress has been made in many of these areas, although implementation of the reform agenda has been slower than expected, in part, due to difficulties in reaching a political consensus. The apparent lack of a comprehensive strategic plan for non-oil sector development has led to piecemeal and ad hoc efforts toward reforms in various areas, which may not enable Kuwait to realize its national objectives, and over time its economic performance could fall behind other GCC countries. Although investment in the economy has increased significantly in recent years, gross domestic investment as a percent of GDP has remained low (14 percent in 2004).

\footnotetext{
${ }^{1}$ Kuwait's relations with the Fund and the World Bank are summarized in Appendixes I and II, respectively. Data issues are covered in Appendix III.

${ }^{2}$ Kuwait continues to depend heavily on foreign workers which increased by about 47 percent during the period 2000-end-June 2005, and they comprise nearly two-thirds of its population of 2.9 million and four-fifths of its labor force of 1.7 million in June 2005.

${ }^{3}$ Oil accounted for 50 percent of Kuwait's GDP in 2000-05, and Kuwait remains one of the least diversified economies in the GCC region.
} 


\section{B. Recent Macroeconomic Developments and Structural Reforms, 2004-05}

\section{Kuwait's macroeconomic performance has been strong in 2004 and 2005}

(Table 1). Real GDP expanded at an average rate of 7.5 percent, as a result of higher oil production and buoyant non-oil activity (6.4 percent). ${ }^{4}$ After taking into account the terms-of-trade gains, per capita GDP increased by 43 percent to more than $\$ 26,000$ during the two-year period through 2005. Inflation remained low at 1.3 percent in 2004 , although it rose to almost 4 percent in $2005,{ }^{5}$ due to rising non-oil activity, abundant liquidity, and the delayed effect of the depreciation of the dinar against the euro and yen. The weighted stock price index (WPI) more

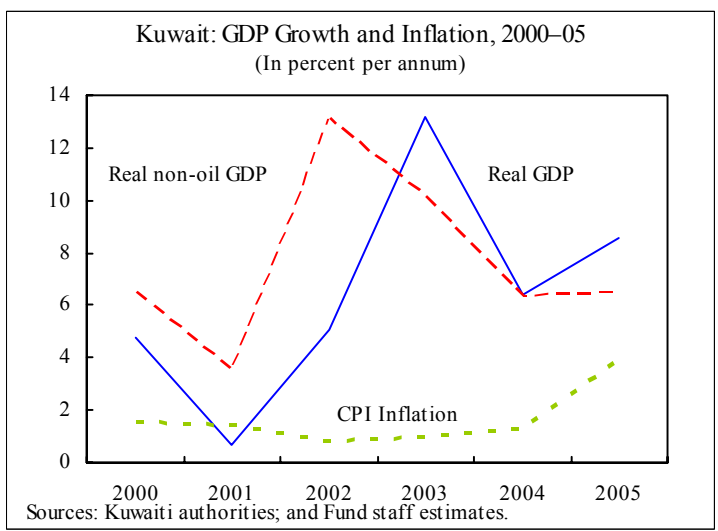
than tripled during 2003-05, although the pace of increase over the recent two-year period (averaging 39 percent annually) has been slower than in other heavily oil-endowed GCC countries, in part reflecting a tighter monetary policy stance (Box 1).

\section{Central government budgetary position strengthened further due to higher oil revenues, with the overall fiscal surplus estimated at 24 percent of GDP in 2004/05 ${ }^{6}$}

(Table 2). Fiscal policy was expansionary in 2004/05, as expenditures increased by more than 14 percent and the non-oil primary deficit in relation to non-oil GDP increased by 4 percentage points to 61 percent. The expansionary fiscal stance was primarily attributable to sharply higher subsidies and transfers and higher capital outlays, while the growth in the wage bill was moderate and

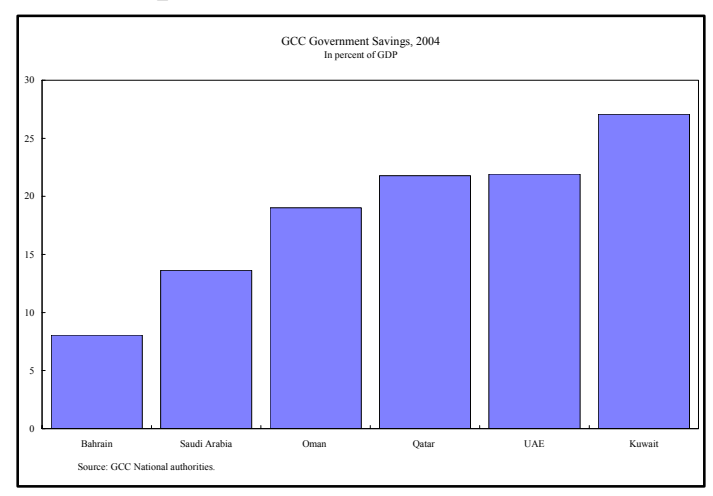

\footnotetext{
${ }^{4}$ Construction, financial institutions, insurance, personal and household services, and transport, storage and communications sectors contributed significantly to the non-oil sector growth witnessed during 2004-05.

5 The increase in the inflation rate has been low partly because of unchanged administered prices of petroleum products and utilities and an open and flexible labor market. The housing component of the CPI which has a weight of 26.7 percent in the overall index and includes house rent, water, fuel and power increased by only 0.8 percent in 2004 and by 0.3 percent during January-October 2005, in part because of unchanged utility prices. The prices of water, fuel, and power are administered and have largely remained unchanged since 2000 .

${ }^{6}$ The fiscal year in Kuwait covers April 1 through March 31 of the following year.
} 


\section{Box 1. Kuwait Stock Market: Recent Developments and Some Characteristics}

Stock prices and market capitalization continued to grow at an accelerated pace. After outperforming most markets in the region in 2003, the Kuwait Stock Exchange (KSE) WPI grew by 15 percent in 2004. The market was more bullish in 2005 , helped by the surge in oil prices, expanding liquidity, and strong corporate performance. As a result, the WPI increased by 67 percent. Market capitalization remained stable at 135 percent of GDP in 2004 and grew to the equivalent of 191 percent of GDP in 2005.

\section{Despite the strong growth, the increase in the WPI} since 2004 has been moderate in comparison to other GCC markets. The average price index for the stock markets of Arab countries during 2004-05 increased by 215 percent, well above the 93 percent gain in Kuwait during the same period. The valuation of Kuwaiti stocks, as measured by their price/earnings ratio (PER), price/book value ratio (PBR), and dividend yield compares favorably with other markets in the region and even with mature markets.

The relatively moderate growth in Kuwaiti stock prices results from a combination of strengths and weaknesses. The new prudential and monetary measures introduced by the CBK in 2004 and 2005 have effectively contributed to the deceleration in the rate of private sector credit growth. However, it may also be related to KSE's relatively weak legal, regulatory, and supervisory framework (as noted in the 2004 FSAP report). Also, according to market participants, a sizable part of listed companies' profit growth is attributable to capital gains on stock investments.

The financial system is well equipped to withstand any reasonable correction. Strong economic fundamentals, in particular high corporate profitability underpinned by high oil prices have provided a solid basis for the increase in stock prices. However, some level of speculative demand, mainly concentrated in volatile stocks with low market capitalization, is pushing prices beyond some firms' economic value. In addition, the market remains very sensitive to external factors such as a decline in oil prices, which may substantially reduce corporate profits. Financial stability is based on strong bank capitalization (capital adequacy ratio of 17.3), household borrowings guaranteed against salaries, and moderate exposure to equity market risk (at 9 percent of total loan portfolio, including non-Kuwaiti securities). Nonetheless, in the event of a substantial correction, profitability of financial institutions would significantly decline and non-oil GDP growth would be negatively impacted through wealth and balance sheet effects.
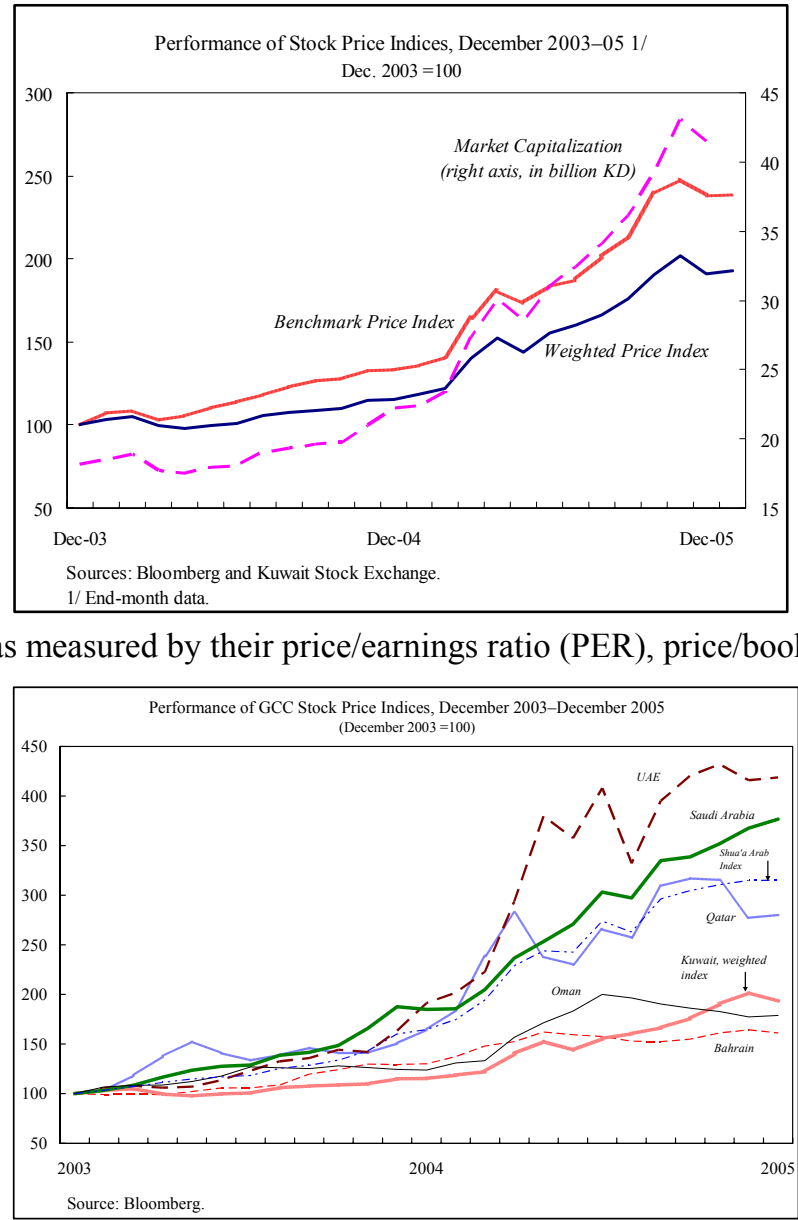

\begin{tabular}{|lccc|}
\hline \multicolumn{4}{|c|}{ Key Stock Market Indicators 1/ } \\
\hline & PER & PBR & $\begin{array}{c}\text { Dividend Yield } \\
\text { (percent) }\end{array}$ \\
\hline Dow Jones Average & 20.97 & 3.06 & 2.28 \\
S\&P 500 & 18.28 & 2.80 & 1.77 \\
Saudi Arabia & 45.20 & 10.10 & 1.30 \\
Kuwait & 13.14 & 3.23 & 1.90 \\
Korea & 11.92 & 1.63 & 0.95 \\
Egypt & 27.68 & 7.97 & 2.70 \\
\hline Source: Bloomberg, Bakheet Financial Advisor, \\
and Global Investment House. \\
1/ All data as of end-January 2006 \\
\hline
\end{tabular}


expenditures on goods and services declined after a sharp pickup in 2003/04 associated with emergency security spending. Overall, two-thirds of the increase in hydrocarbon revenues is estimated to have been saved in 2004/05, and Kuwait's government saving rate of 28 percent of GDP in 2004/05 was the highest amongst all GCC countries.

5. The external current account registered annual surpluses averaging $\$ 25$ billion (37 percent of GDP) during 2004-05, primarily on account of high oil revenues. At an annualized rate, exports of oil and oil products increased by over 47 percent, but non-oil export $^{7}$ growth slowed down to 15 percent compared with a surge of about 70 percent in 2003 (Table 3), because of slower growth of reexports to Iraq. Import growth remained high as a result of strong domestic economic activity. Although the services account deficit widened because of higher payments associated with travel and transportation, it was more than offset by higher investment income which surged by 59 percent on an annualized basis. The real effective exchange rate (REER) of the Kuwaiti dinar depreciated by 5 percent in 2004;

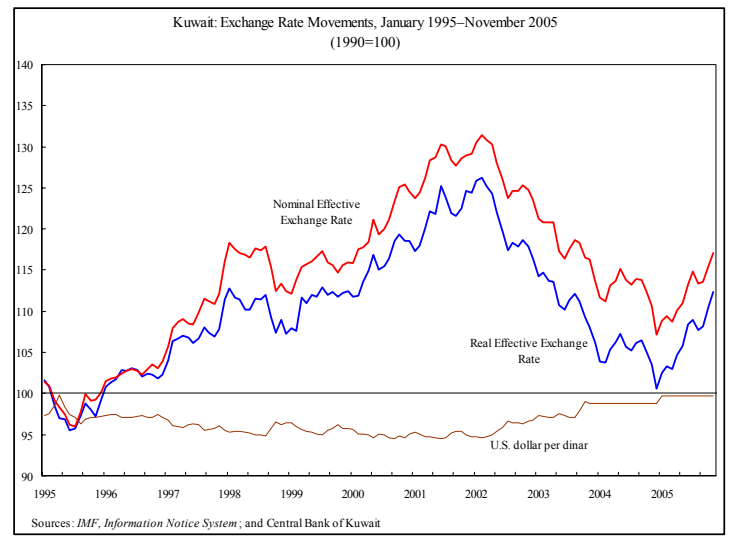
however, with the strengthening of the U.S. dollar vis-à-vis other major currencies in recent months, the REER appreciated by 11.7 percent during January-November 2005.

\section{Broad money growth steadily accelerated during 2004-05 and grew by}

16.7 percent during the 12-month period through September 2005, despite efforts to tighten monetary policy. This accumulation is attributable to the expansion of credit to the private sector (13.1 percent of broad money) and an increase in net foreign assets (15.7 percent of broad money) (Table 4). The tightening of monetary conditions since the second half of 2004 was pursued by increasing the benchmark interest rate in line with global interest rate developments, by introducing a ceiling on the credit to deposits ratio in July 2004, and by the re-introduction of market-based monetary control mechanisms in August 2005. Banking supervision has strengthened further, and the

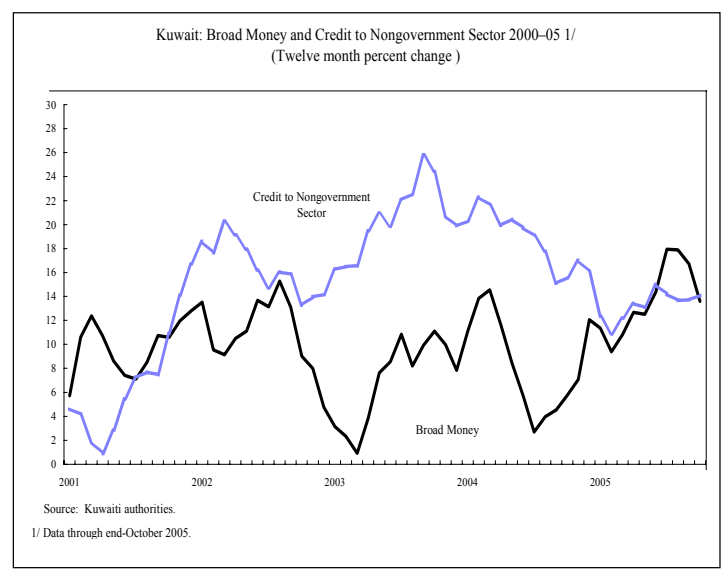

${ }^{7}$ Petrochemicals and manufactured fertilizers accounted for 45 percent of non-oil exports (excluding re-exports) in 2003. 
CBK applied the Basel II capital adequacy requirements for conventional banks effective December $31,2005 .{ }^{8}$ The banking sector has been opened further for foreign banks, ${ }^{9}$ but progress on implementing the remaining FSAP recommendations has slowed down since most pending actions entail legal changes. ${ }^{10}$

\section{Some progress has been made in private sector participation in the sectors} previously dominated by the public sector (particularly in telecommunications, airlines, and infrastructure development). However, several draft laws (including the privatization and competition laws) aimed at promoting a more market-friendly business environment have been awaiting parliamentary approval for a long time due to a lack of political consensus. The Kuwaitization ${ }^{11}$ policy has been in place since October 2003, entailing the training of unskilled Kuwaiti nationals and enforcing quotas by imposing penalties to increase the proportion of nationals in the economy. ${ }^{12}$

\section{REPORT ON DISCUSSIONS}

\section{The discussions primarily focused on the following four areas which are} considered critical for medium- and long-term growth and macroeconomic stability. These include (a) the authorities' current plan regarding capacity expansion in the hydrocarbon sector and its contributions to the medium-term growth and financial outlook; (b) the fiscal strategy to deal with surging surpluses in a way that contributes to growth through higher investment, fosters an increased role for the private sector in infrastructure development and service delivery, and also addresses intergenerational distribution of wealth; (c) the short- and medium-term challenges for the financial sector, including the potential vulnerabilities arising from the recent asset market developments; and (d) the needed structural reforms to sustain the recent pickup in non-oil activity. The discussions

\footnotetext{
${ }^{8}$ The authorities also adopted a prudent approach to the introduction of Islamic banking, legally requiring that Islamic and non-Islamic financial operations are conducted in separate institutions and limiting the number of licenses issued during the first phase.

${ }^{9}$ Three foreign banks have already opened branches in Kuwait in 2005 and a fourth license has been issued.

10 The main remaining FSAP recommendations that would require legal changes are: strengthening of the regulatory and supervisory framework for the capital market and insurance companies; criminalizing the financing of terrorism; granting full independence to the $\mathrm{CBK}$; and removing interest rate ceilings on lending.
}

\footnotetext{
11 The Kuwaitization policy aims at increasing the proportion of Kuwaitis employed in the private sector by establishing targets (proportional to the workforce) that the nongovernment companies must observe. The proportion varies from sector to sector. Nongovernment companies not complying with the established limits are not allowed to conclude contracts or do business with the government.

12 Although more than 85 percent of the Kuwaiti national labor force is employed by the public sector, the percentage of Kuwaiti nationals who found jobs in the public sector has declined from 72.3 percent in 2003 to 59.5 percent during January-November 2005.
} 
were cast in the context of the near- and medium-term outlook for the Kuwaiti economy and the underpinning policies.

\section{A. Near- and Medium-Term Outlook Remains Strong}

\section{Real GDP is projected to grow by 6.2 percent in 2006 , supported by continued} strong oil and non-oil activity. Oil production is expected to remain close to Kuwait's production capacity of $2.7 \mathrm{mbd}$. Inflation is expected to decelerate somewhat to 3.5 percent as a result of moderation in rental costs and unchanged administered prices for utilities. Both the external current account and the overall fiscal surpluses are projected at more than 40 percent of GDP, ${ }^{13}$ despite higher public spending including the full-year effect of the increase in public sector wages by about 10 percent effective July 2005.

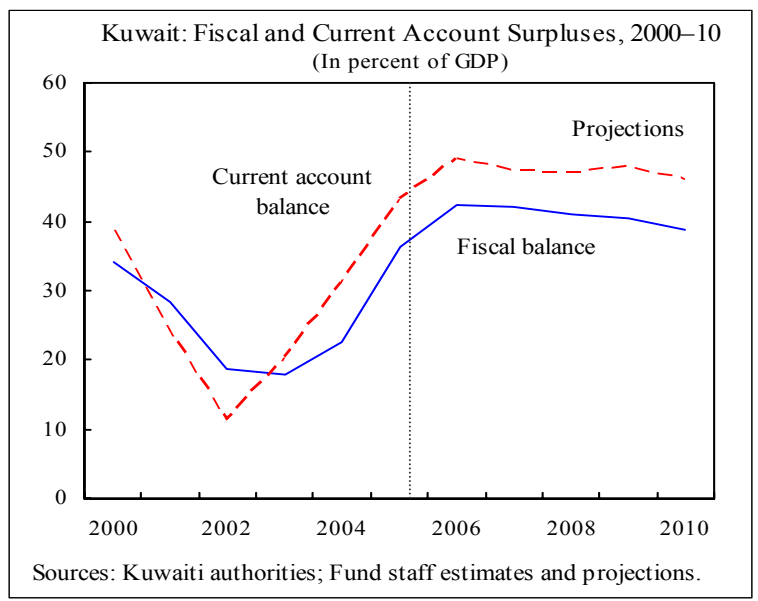

10. Over the medium term (2007-10), Kuwait's financial position is projected to remain strong. Both the external current account and fiscal balances will remain in large surplus, albeit at modestly declining levels in relation to GDP, mainly reflecting the projected slow decline in oil prices. The fiscal and current account outlooks are expected to be favorably influenced by the returns from the accumulated assets of the Reserve Fund for Future Generations (RFFG). Although the surpluses are expected to remain large despite a moderate decline in oil prices, the authorities observed that there are downside risks to this favorable mediumterm financial outlook since it is based on

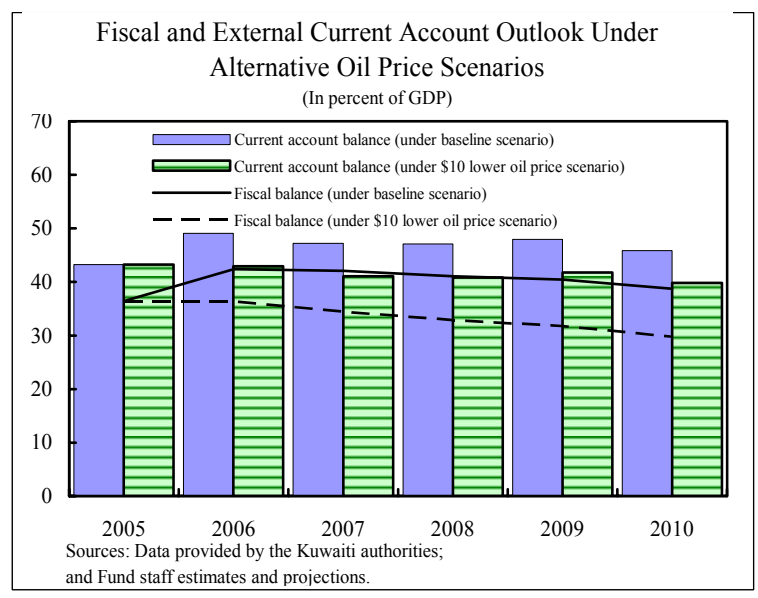
historically high levels of oil price and output assumptions. ${ }^{14}$ On the fiscal side, although total expenditure in relation to GDP is assumed to remain broadly unchanged over the medium term, these projections entail a significantly lower growth in current outlays than experienced in recent years. Prospects for private investment and non-oil GDP growth are

\footnotetext{
${ }^{13}$ Based on the latest (December 2005) oil price projection of the World Economic Outlook (WEO).

${ }^{14}$ On the assumption of an oil price that is $\$ 10$ per barrel below the present WEO medium-term oil price outlook, staff estimates indicate that the fiscal and current account surpluses will decline by about 9 percentage points in relation to GDP over the medium term to reach 30 and 39 percent, respectively.
} 
expected to weaken over the medium term in view of the expected slow pace of structural reforms. GDP growth is also expected to decelerate as oil production stabilizes at the projected $3 \mathrm{mbd}$ level, in line with the envisaged oil-sector investment plan.

\section{B. Hydrocarbon Sector: Is the Investment Plan Supportive of Global Oil Market Stability and Kuwait's Growth Potential?}

\section{Kuwait's constructive role in support of oil price stability entailed a rapid} expansion of crude output, a comprehensive plan to expand crude and refined oil output, and a boost to gas production for domestic uses (Box 2). Production of crude oil has been increased by 47.5 percent since 2002 in response to growing world demand. A \$22 billion self-financed plan to expand crude oil capacity to $3 \mathrm{mbd}$ by 2008 , increase refining capacity by 60 percent, and almost double the production of petrochemical products is under implementation. Staff supported these plans and underscored that sustained growth in hydrocarbon output would be important for Kuwait's medium-term growth outlook and would

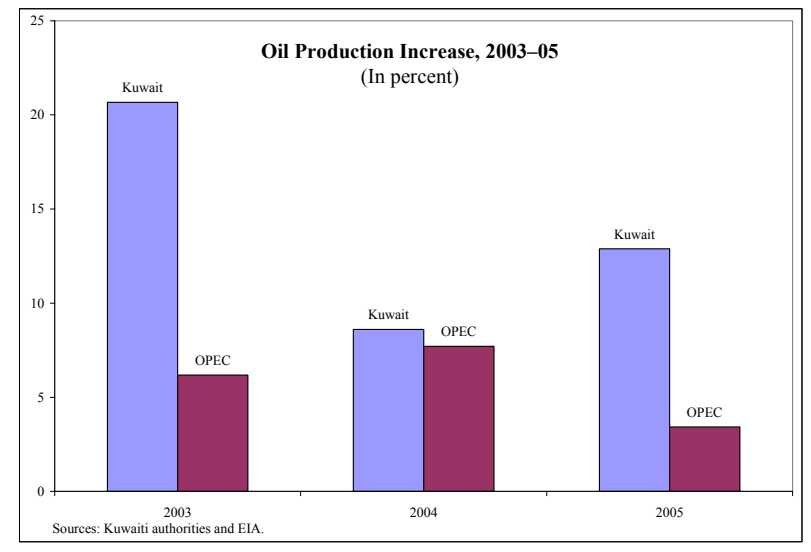
also contribute to global oil market stability. Forging the necessary political consensus for developing expeditiously the North Fields under "Project Kuwait," which the authorities have been contemplating since 1997, would be critical for the success of their expansion plans. The authorities now hope that, given the broad political consensus reached on Project Kuwait, parliamentary approval should be possible in early 2006. Kuwait is contributing to oil market transparency by providing data to the Joint Oil Data Initiative (JODI), although there is scope for improving the timeliness of oil data provision. 


\section{Box 2. Hydrocarbon Sector Investment Plans, 2006-11}

Kuwait has 99 billion barrels of proven oil reserves, approximately 8 percent of world oil reserves, and is undertaking a broad-based investment plan to realize its hydrocarbon sector potential over the medium and long run. In this context, a $\$ 10$ billion program to increase crude oil production capacity to 3 mbd by 2008 is under implementation, which is a part of the government's $\$ 22$ billion plan and is in line with the long-term plan to increase capacity to $4 \mathrm{mbd}$ by 2020 . The long-term expansion plan critically depends on the implementation of "Project Kuwait", which complements the government's own plan with an additional investment of $\$ 8$ billion, jointly with foreign oil companies. Under this project, Kuwait is considering permitting foreign oil companies to invest in upstream production on "buy-back contract" arrangements,

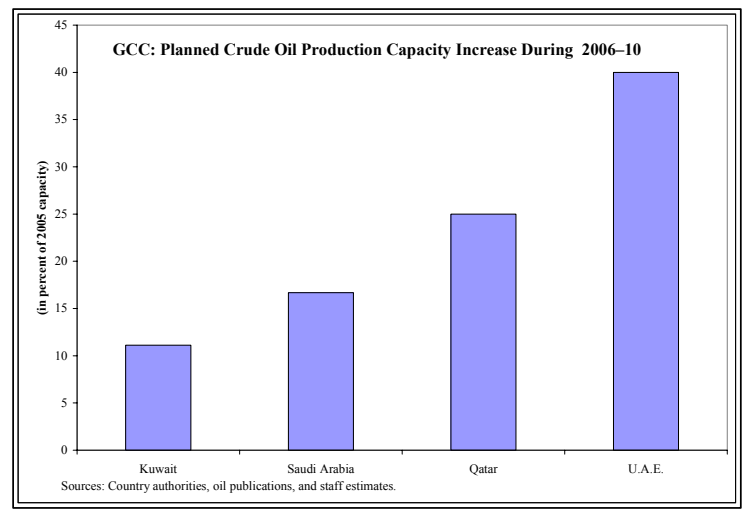
which do not involve production sharing, concessions, or the "booking" of reserves by foreign companies. Project Kuwait has been delayed repeatedly due to a lack of political consensus, although there are signs that legislative approval could be secured soon.

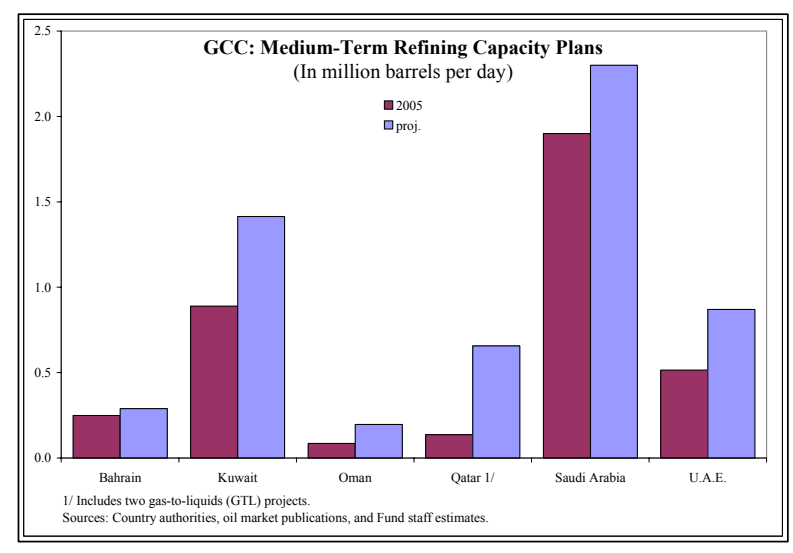

As part of its long-term plan, Kuwait is also planning to spend over $\$ 10$ billion through 2011 to upgrade and increase its petroleum refining capacity. Total refinery capacity is expected to increase from the current level of $0.9 \mathrm{mbd}$ to $1.4 \mathrm{mbd}$ by 2011 . The upgrade would increase capacity to produce ultra-lowsulphur fuel, and to process an increasing proportion of domestic heavy and sour crude.

Kuwait produces a relatively modest volume of natural gas (around 293 billion cubic feet in 2003), the vast majority of which is "associated gas" that is extracted in conjunction with oil. Kuwait's natural gas reserves are estimated to be 55 trillion cubic feet, equivalent to 200 years of reserves at the current level of production. Kuwait hopes to significantly increase its use of natural gas, especially in electricity generation, water desalination, and petrochemicals plants, by increasing gas supplies from domestic and imported sources and by reducing the flaring of associated gas to one percent by 2009 from six percent currently.

Development of Kuwait's petrochemicals sector is being accelerated through an investment plan of $\$ 1.5$ billion. The plan includes the Olefins project (also called Equate II) to produce ethylene, polyethylene, and ethylene glycol; and the aromatics and styrene plants that are expected to come on stream by 2008 . The Equate joint venture is the country's largest petrochemicals project. 


\section{Fiscal policy: Improving Resource Management and Ensuring Long-Term Fiscal Viability}

\section{The overall fiscal position is projected to remain in comfortable surplus over the} medium term. Accordingly, the discussion focused on improvements in the structure of the budget by gradually increasing capital expenditure, rationalizing transfers and subsidies, and achieving a better balance between productive expenditure and fiscal savings. ${ }^{15}$ Staff supported the authorities' plans to use a part of the higher oil revenue to further improve the country's physical infrastructure and for investments in health and education. In this context, the staff urged the authorities to promote greater private sector participation in these projects including through public-private-partnerships (PPP). In response to staff's observation that there was ample room for further boosting public investment by accelerating the implementation of strategically important infrastructure projects, the authorities observed that several such initiatives are under consideration, ${ }^{16}$ although many of them would require consensus building at the domestic and regional levels.

\section{The current favorable fiscal situation is likely to give rise to expenditure} pressures, which are already evident in the area of wage and salary increases and higher subsidies and transfers. Staff cautioned against a further widening of the public-private sector wage differential, which would hinder private sector development and further increase the need for wage subsidies to encourage the employment of Kuwaiti nationals in the private sector. While concurring with the staff, the authorities observed that they were trying to fend off such pressures, and the recently announced moderate increase in general salary was a manifestation of their efforts. The authorities also reaffirmed their intention to implement stricter rules for additional recruitment in the public sector, limiting new recruitment to actual staffing needs, and increasingly linking salaries and allowances to individual performance.

\section{Progress in the area of income tax reform has stalled, and a revised strategy needs to be explored in light of the current favorable fiscal outlook and political} feasibility. The authorities indicated that the envisaged introduction of a new income tax on national companies might not be politically feasible in the current macroeconomic environment. Against this background, staff suggested rationalization of tax and expenditures in order to encourage foreign direct investment and improve efficiency of spending. The measures suggested include: cutting the prevailing 55 percent maximum income tax rate on foreign companies to 15-20 percent in line with other GCC countries; and a significant reduction in large and untargeted subsidies and transfers by rationalizing the system, which

\footnotetext{
${ }^{15}$ While last year's staff report (Country Report No. 05/231) noted that the fiscal stance was not sustainable at the oil prices projected at that time, fiscal sustainability is not an issue given the current, markedly higher, projected oil price path. In view of the large net assets position built up by the public sector, Kuwait can sustain a balanced overall fiscal position at $\$ 17$ per barrel in real terms. The fiscal stance envisaged under the mediumterm scenario would also allow for sustaining an unchanged net assets to GDP ratio, with oil prices at $\$ 25$ per barrel in constant terms.

${ }^{16}$ See paragraph 23.
} 
accounted for 30 percent of total expenditure in $2004 / 05 .{ }^{17}$ The authorities observed that an initiative to introduce a Value Added Tax (VAT) in Kuwait in coordination with other GCC countries was continuing. While supporting this step, staff encouraged the authorities to implement the budgetary reforms they had been contemplating in recent years, including the introduction of a three-year rolling budget; consolidation of the budgetary process by bringing all budgetary chapters under the ministry of finance; and adoption of budget classifications in line with international accounting standards.

\section{The large fiscal surpluses have created both opportunities and challenges for addressing a number of medium- and long-term issues facing Kuwait (Box 3). The} authorities observed that, although Kuwait's health and education systems and physical infrastructure were quite good, substantial additional allocations for these sectors were envisaged under the forthcoming new five-year plan. ${ }^{18}$ The large investment plan to expand hydrocarbon sector activity would be essentially financed by the Kuwait Petroleum Corporation out of its own resources and its joint venture foreign partners. The authorities were of the view that despite sizable additional allocations, consistent with Kuwait's absorptive and implementation capacity, the fiscal surpluses would still remain very large. Staff underscored that, in the absence of a clear strategy for utilizing the surpluses, pressures would intensify for higher salary increases, a larger size of the government, and larger transfers to Kuwaiti nationals.

\section{While noting that such pressures were indeed building up, the authorities} observed that the government remained committed to proper utilization of the fiscal surplus. Accordingly, the government contributed an additional 5 percent of revenues (in addition to the statutory contribution of 10 percent of all government revenues) to the RFFG in 2004/05 and are likely to do the same in future. The fiscal surplus was also utilized to pay back a part of the amount borrowed out of the RFFG in the aftermath of the Gulf war and the government plans to expedite the repayment of the remaining amount. While endorsing the authorities' approach, staff observed that investment income of the RFFG was already significant and, combined with the anticipated large budgetary surpluses, would likely assume greater importance over time. If resources are well managed, given the current medium-term oil price outlook and fiscal stance, achieving fiscal sustainability and the transition to a predominantly non-oil economy in the long run will be much easier. Accordingly, as regards Kuwait Investment Authority (KIA) assets, the staff underscored the importance of strong safeguard arrangements; continuous oversight by the Board of Directors of the KIA and by parliament; and greater transparency in the management of funds by KIA.

\footnotetext{
${ }^{17}$ In particular, subsidies could be better targeted to low-income families through changes in water and electricity tariff structures and using means testing for various subsidized loan programs.

${ }^{18}$ The medium-term fiscal framework allows for expenditures growing at 5 percent in real terms, excluding the planned large investments in the hydrocarbon sector.
} 


\section{Box 3. Kuwait: How Should the Fiscal Surpluses be Used?}

The authorities face the challenge of managing the large fiscal surpluses efficiently. Kuwait has built up sizable investments abroad, despite the setback of the 1990-91 Gulf war. The assets are likely to be built up at a faster pace in the coming years because of higher oil revenues. Accumulated public sector savings is projected to reach 300-400 percent of GDP over the next 58 years, contributing about $15-20$ percent of GDP per annum in implicit returns and thereby greatly strengthening Kuwait's fiscal position even in the event of a decline in oil prices. However, fundamental decisions will

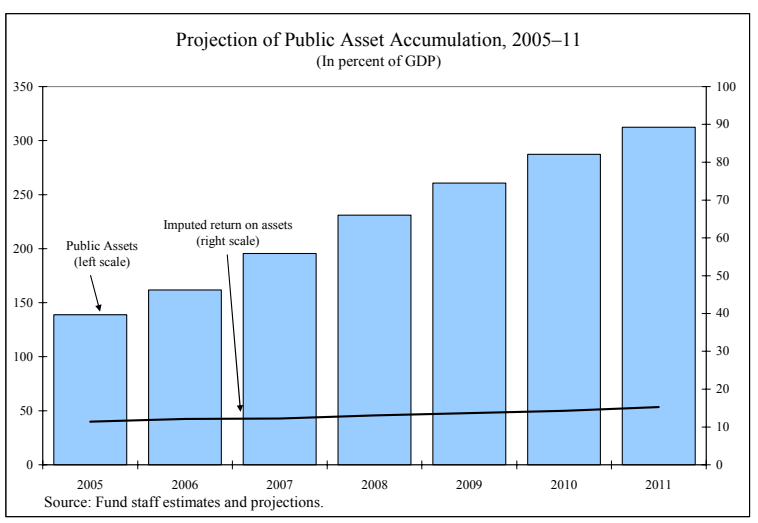
have to be made on how to allocate the available funds between productive uses.

Despite the very high level of savings, the level of domestic investment in Kuwait is still rather low and public investment is lagging far behind that of other oil-exporting countries in the region.

There appears to be room for further boosting capital expenditure for infrastructure development, health, and education. Efficient government investment in infrastructure and human capital would also contribute to intergenerational equity by enhancing the economy's long-term growth potential. However, such needs are not likely to be excessive given that Kuwait has already built up good quality infrastructure.

The fiscal surpluses could also be used to recapitalize Kuwait's social security system (KPISS), which has accumulated significant actuarial deficits in the past. KPISS suffers from a serious structural imbalance because of excessively generous benefits and very low contributions. The last actuarial evaluation of the KPISS done in 2001 indicated that funds of the basic system would be depleted within the next 15 to 25 years if no corrective measures were taken. The actuarial deficit of KPISS has continued to increase since the last valuation, the cumulative actuarial deficit growing from KD 5.5 billion in 1998 to around KD 7 billion in 2004. Therefore, any recapitalization operation should be linked to a fundamental and much-needed reform to guarantee

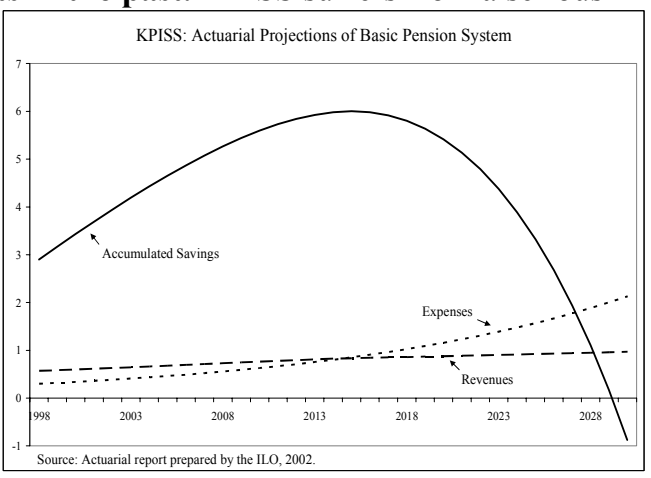
the system's long-term viability.

Finally, a large part of the projected fiscal surpluses should continue to be used in further accumulating financial assets to ensure fiscal sustainability over the long term and to take account of intergenerational equity issues with regard to the intertemporal distribution of Kuwait's oil wealth. Even though the country's large natural resource endowments will generate significant government revenues over a long time, economic policy in the long run would need to address the transition to a situation where the oil resources/revenues would be depleted. Investment income from financial savings, if appropriately built up, would help Kuwait to preserve public sector wealth and maintain public services in future. 
17. Despite the current surplus position of the Kuwait Public Institution for Social Security (KPISS), it cannot be considered financially sound in the long run. ${ }^{19}$ The authorities are aware that with payments growing faster than contributions and investment income over the long run, the institution's financial balance will turn into deficit by the end of the next decade and assets will be eventually depleted, if no corrective measures are taken. The authorities agreed with the staff that the current large fiscal surpluses have created an opportunity to ensure the long-term viability of the KPISS if it is reformed in an appropriate and socially balanced manner. This would entail rationalization and reduction of the overly generous benefits and realignment of contributions in line with the benefits. In the context of such a reform, the staff encouraged the authorities to recapitalize KPISS for the actuarial shortfalls accumulated in the past, as provided under the Social Security Law, thereby establishing a fully-funded and sustainable social security system.

\section{Monetary and Financial Sector Policies: Promoting Financial Intermediation While Safeguarding Macroeconomic Stability}

\section{Monetary policy has been successful in maintaining price stability and the} exchange rate peg. Although the underlying equilibrium exchange rate might have appreciated with the positive terms-of-trade shock resulting from higher oil prices, given Kuwait's limited non-oil export base and its commitments in the context of the GCC, the authorities do not foresee a change in the exchange rate peg to the U.S. dollar in the period leading up to the planned establishment of the monetary union by 2010 . The authorities are aware that given the nominal peg to the U.S. dollar, in theory there could be some inflationary pressures in the economy leading to an appreciation of the real exchange rate. However, given Kuwait's very open trade regime and relatively open labor market, they do not foresee any significant inflationary pressure in the medium term. The pick up in inflation in 2005 would not last very long, the authorities observed, as the supply of housing would increase given the construction boom underway and prices of raw materials should stabilize in the world market. At this point, all options remain open regarding the exchange rate regime under the monetary union.

\section{The reintroduction of market-based monetary policy mechanisms also have} contributed to maintaining price and exchange rate stability. The auctioning of deposits and issuance of 3-month CBK bonds to mop up excess liquidity helped keep KD deposit rates in line with the CBK's benchmark rate since August $2005 .{ }^{20}$ As a result, KD bank deposit rates have increased substantially and the differential with U.S. dollar deposits,

\footnotetext{
${ }^{19}$ Actuarial valuations indicate that the present value of assets amounts to less than 60 percent of the present value of future liabilities.

${ }^{20}$ Banks whose KD deposit rates are above a certain threshold (determined by the CBK) are allowed to purchase CBK bonds at a pre-determined yield. As of end-October 2005, all bond purchases requested by qualifying banks have been satisfied. Bond yields are set close to the CBK-determined threshold. In addition, auctions of deposits are done daily through over-the-counter calls to banks' treasurers.
} 
which was negative during the first half of 2005 , became positive again in the third quarter of the year. While welcoming these developments, staff noted that enhancing effectiveness of the marketbased intervention will require closer coordination with fiscal policy - which continues to be the major source of liquidity expansion in the economy - to determine the level of intervention.

\section{The ceiling on the loans-to-deposits ratio} achieved its intended objective by dampening the rate of credit growth during $2004-05^{21}$ and

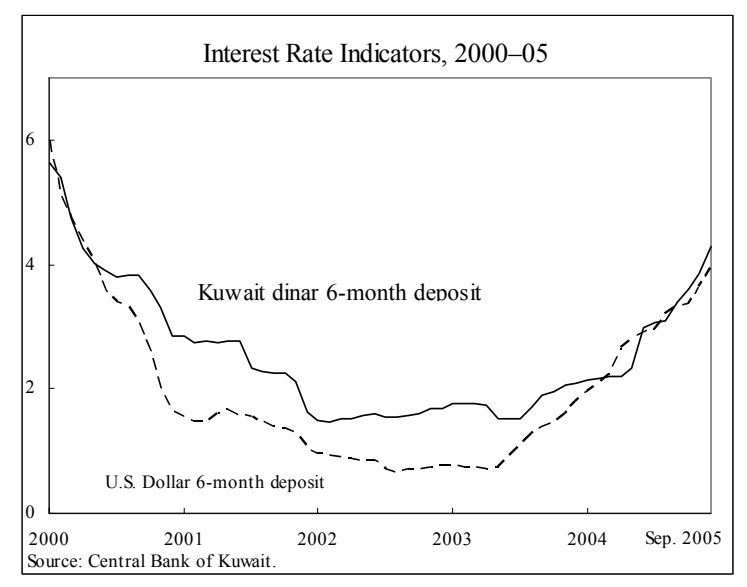
thus contributed to the comparatively slower equity price increase. With the deposit growth rate increasing to 16.4 percent, it also restored the balance between the rate of growth of credit and deposits. ${ }^{22}$ However, staff noted that despite these positive effects, the ceiling on the loans-to-deposits ratio, in combination with the ceiling on lending rates, might be interfering with the efficient allocation of resources. ${ }^{23}$ For these reasons, and taking into account the further gains made in strengthening banking supervision, staff recommended that consideration should be given to abolishing the ceiling if the situation remains stable and to ease the ceilings on lending rates within the authority of the $\mathrm{CBK} .{ }^{24}$ In the authorities' view, in practice neither of these ceilings were affecting negatively the allocation of financial resources nor were they constraining the activities of banks or nonfinancial firms. However, they observed that the loans-to-deposits ratio was becoming increasingly less effective with the accumulation of excess loanable resources by banks and considered the ceiling a temporary measure to be eliminated once the risk of credit expansion above deposits disappears.

\section{The authorities agreed with the staff assessment that the continuing upward} trend in the stock price index, despite strong economic fundamentals, posed some risk to the otherwise favorable financial sector outlook. The exposure of banks to the stock market through lending for stock purchases (9.4 percent of domestic credit as of end-October 2005 ) and the continuing surge in stock prices in the final quarter of 2005 warrant close monitoring. Staff recommended expeditious drafting and passage of the capital market and insurance laws to establish capital market and insurance authorities that will ensure

\footnotetext{
${ }^{21}$ The rate of growth of credit to the private sector decelerated from 21.4 percent in 2003 to 16.1 percent in 2004 and to 14.1 percent in the 12-month period through October 2005.

${ }^{22}$ In addition to the growth in economic activity, the increase in interest rates and the buildup of government deposits with the domestic banking system also contributed to the growth of deposits.

${ }^{23}$ Conceptually this may increase the number and proportion of loans contracted at the binding lending rate ceilings and may constrain credit supply for the middle corporate market.

${ }^{24}$ Although eliminating the lending rate ceiling will require a legal change in the CBK law, the current law allows the CBK to fix these ceilings.
} 
comprehensive oversight of the stock exchange, investment companies, and the insurance sector. Staff also called for strengthening the legal and technical capabilities of the KSE to supervise the investment companies' portfolio management and for enhancing coordination with the $\mathrm{CBK} .{ }^{25}$ While broadly agreeing with the staff assessment, the authorities underlined that the stress tests conducted by the CBK, including both direct and indirect equity market risks, showed an adequate and increasing resilience of the banking system against any reasonable market correction. ${ }^{26}$ The staff supported the authorities' intention to introduce a limited deposit guarantee scheme fully funded by contributions from the banks and urged them to implement the scheme expeditiously.

\section{E. Structural Reform: How Can Kuwait Sustain Its Non-Oil Growth Momentum?}

\section{The current non-oil sector growth momentum is attributable to the optimism} associated with the oil price outlook and private sector dynamism observed across the GCC region. The authorities agreed with staff that a critical mass of structural reforms, including amending outdated laws and regulations, would need to be implemented in order to sustain the growth momentum and promote a more market-friendly business environment. In this context, staff supported the authorities' intention to legislate the Competition Law and implement a legal framework for mega projects under the PPP program. Staff also encouraged the authorities to: implement the remaining recommendations of the 2003 World Bank report on "Administrative Barriers to Investment", including updating of the Labor Law which dates from 1964; eliminating the discretionary power in the system for the registration of companies; and continuing the customs administration modernization. The authorities acknowledged that creation of a market-friendly environment would also entail the long-awaited parliamentary approval of the Privatization Law. Staff also encouraged the authorities to consider market-based pricing of publicly provided goods and services, particularly for electricity, petroleum products ${ }^{27}$ and water to improve resource allocation, encourage private sector participation in these activities, and reduce fiscal subsidies.

\section{Various measures were implemented aiming at greater market access and competition and allowing for a broader private sector role in the economy. However, there is a need to cast these measures in the context of a comprehensive reform} strategy. The GCC common external tariff at 5 percent rate is in effect since early 2003, and

\footnotetext{
${ }^{25}$ The KSE started to supervise the portfolio management services provided by investment companies in 2005. The KSE's supervisory role is hampered by the lack of legal backing to regulate and supervise investment advisory services, and by its relatively weak technical expertise. The 2004 FSAP recommended establishing a single regulator for all capital market segments and participants. Until this recommendation is implemented, coordination with the CBK needs to be strengthened so as to ensure that all risk areas of investment companies are looked into, criteria are uniformly applied, and unnecessary administrative burdens are avoided.

${ }^{26}$ However, the authorities agreed with staff that there was scope for improved transparency through implementation of more comprehensive accounting standards for financial and nonfinancial companies.

27 Domestic petroleum product prices were broadly market based (entailing no economic subsidy) until 2002. However, with domestic prices remaining unchanged, they now stand at about one-half of international prices.
} 
under the Greater Arab Free Trade Area (GAFTA) initiative all import duties were eliminated in January 2005. The GCC countries have agreed to negotiate FTAs with other countries/regional blocks collectively in the future, and an FTA with the European Union is expected to be signed later this year. ${ }^{28}$ The granting of licenses for three airlines and four more private universities, allowing private companies to operate gas stations, and building two new power plants are also steps in the right direction. The authorities noted that construction of a port on the Boubiyan Island (a joint venture) which is likely to be operational in 2008, privatization of port management, the proposed North-South GCC train line and the initiatives taken under GAFTA would help in their strategy to make Kuwait a regional trade and financial center. Staff also supported the authorities' efforts to foster foreign direct investment (FDI) by amending the FDI Law of 2003 in line with international best practices. $^{29}$

\section{The authorities are aware that sustaining the current growth momentum will} require a flexible application of the Kuwaitization policy and intensified efforts to raise the skills of the Kuwaiti labor force. Staff noted that providing employment in the public sector to alleviate unemployment pressures, as has been done in the past, raises reservation wages for private sector jobs and reduces the incentives for acquiring skills needed for private sector jobs. Accordingly, staff urged the government to limit public sector hiring to essential areas, establish links between public sector wages and productivity, and rationalize public sector benefits. Staff encouraged the authorities to consider positive incentive schemes rather than negative incentives to achieve Kuwaitization goals. ${ }^{30}$

\section{F. Statistical and Other Issues}

\section{While the quality of economic data continues to improve, the lack of timely} availability of some key economic data on the official websites remains an obstacle for dissemination of information. Significant progress was made in timely provision of the CPI and WPI, and the authorities' are planning to conduct an investment survey in order to better measure nonfinancial foreign direct investment. Staff encouraged the authorities to improve communications between the various government agencies including the customs agency, the ministry of planning, and the CBK, in order to improve compilation of the national income and balance of payments data. The authorities observed that the planned Establishment Census (expected to be completed in 2006) would enable the construction of a new macroeconomic framework for collection and compilation of national income data. Staff called for improving the coverage of export data, collection of private sector external debt

\footnotetext{
${ }^{28}$ Discussions on FTAs are also continuing with China and India.

${ }^{29}$ The proposed amendments include: making the Foreign Investment Bureau an independent and fully operational body; creating a "negative list"; and allowing international arbitration.

${ }^{30}$ These positive incentives include: (a) enhancing the current education and training programs; (b) establishing job matching and job counseling programs; and (c) providing low-cost funds to nationals to start their own business.
} 
data, and coverage of fiscal data. ${ }^{31}$ Staff supported the authorities' intention to work out a road map for subscribing to the Funds' Special Data Dissemination System (SDDS) and encouraged them to adopt common data standards across all sectors, in collaboration with other GCC countries, to ensure compliance with convergence criteria for the proposed monetary union.

\section{Kuwait continued to support low-income countries (LICs) through its sizable} external development assistance program. In 2004/05, the Kuwait Fund for Arab Economic Development made commitments of KD 201 million (1.2 percent of GDP) in grants and loans to finance 25 projects in 22 countries. The authorities are considering the Iraqi request to cut Iraqi debt owed to Kuwait, and have committed to provide economic support for Iraq, ${ }^{32}$ the victims of the Asian tsunami (\$100 million) ${ }^{33}$ and hurricane Katrina (\$500 million). Kuwait also disbursed the full amount of its commitment to the HIPC Trust Fund (SDR 4.3 million).

\section{StAfF APPRAisal}

27. Kuwait's macroeconomic performance strengthened further in 2004 and 2005 , reflecting higher oil output and prices and strong non-oil activity. The high pace of economic expansion combined with terms of trade gains, boosted per capita income by 78 percent over the last four years. The saving of a significant part of oil price induced budgetary resources contributed to large fiscal and current account surpluses and an accelerated buildup of external assets for future generations. Kuwait's financial position is also projected to remain strong over the medium term. However, sustaining private sector-led high non-oil growth to absorb the rapidly growing Kuwaiti labor force and diversify the economy remains a major challenge. The apparent lack of a comprehensive strategic plan for non-oil sector development and piecemeal reform efforts, in part due to difficulties in reaching a political consensus, may undermine realization of Kuwait's national objectives and its relative economic performance may fall behind other GCC countries.

\section{Kuwait continues to play a constructive role in support of oil price stability. Oil} production has responded strongly to growing world demand and is currently running almost at full capacity. The large investment plan being undertaken to expand crude oil output capacity, increase refining operations, and almost double petrochemicals production demonstrated the authorities' readiness to support global economic expansion through oil

\footnotetext{
${ }^{31}$ Relating to investment income, transfer of profits of public institutions, and interest payments on treasury bills and bonds.

32 The amount of debt owed by Iraq is estimated at $\$ 8.2$ billion (excluding U.N. war compensation). Kuwait has committed to provide $\$ 500$ million to Iraq in 2004 to finance infrastructure projects and an additional $\$ 60$ million for health and education projects.

${ }^{33}$ Kuwait has also announced a freeze on the repayment of about $\$ 763$ million in loans extended to the six Asian countries affected by the tsunami.
} 
market stability and also realize financial gains for the Kuwaiti population. Staff also urges the authorities to mobilize the required political support to implement the long-delayed Project Kuwait which envisages participation of international oil companies to develop the technically challenging northern oil fields. Staff welcomes Kuwait's contribution to oil market transparency by providing data to JODI and urges the authorities to improve timeliness of oil data provision.

\section{Although Kuwait's overall fiscal position is projected to remain in comfortable surplus over the medium term, staff urges the authorities to consider improvements in the structure of the budget by gradually increasing capital expenditure, rationalizing} subsidies, and achieving a better balance between productive expenditure and fiscal savings. The stance of fiscal policy in 2004/05 and in the current fiscal year, demonstrates the authorities' resolve to contain recurrent outlays despite intensifying pressures for higher current outlays and a larger size of the public sector. Greater emphasis on capital spending envisaged under the five-year plan is welcome, although given the size of the projected fiscal surplus over the medium term, a comprehensive strategy to deal with the surplus issue will be critical in the face of growing pressures for unproductive spending. While supporting the authorities' plan to build up RFFG reserves, staff notes that part of the fiscal surpluses should be used to recapitalize the social security system in the context of a reform program to ensure the system's long-term actuarial soundness. Also key to Kuwait's long-term fiscal viability will be the efficient management of the rapidly growing public sector savings.

\section{Monetary policy has successfully maintained price stability and the exchange}

rate peg. Staff supports the authorities' intention to keep the exchange rate peg unchanged until the GCC monetary union is formed and to remain open toward the choice of exchange rate regime under the planned monetary union. The ceiling on the loans-to-deposits ratio introduced in 2004 to tighten monetary conditions has contributed to a deceleration in the rate of credit growth in 2005 and to a rapid buildup of deposits. In view of the gains already made and the diminishing effectiveness of the ceiling, and taking into account the further gains made in strengthening banking supervision, staff recommends that consideration should be given to abolishing the ceiling.

\section{The Kuwaiti banking system is financially sound, well managed, and well}

supervised. While welcoming the steps taken to further strengthen banking supervision and open further the sector for foreign banks, the staff encourages the authorities to push for necessary legal changes required for implementing the FSAP recommendations relating to criminalization of terrorism financing, independence of the $\mathrm{CBK}$, and renewal of interest rate ceilings. The continuing upward trend in the stock price index, despite strong economic fundamentals, poses some risk to the otherwise favorable financial sector outlook. Staff accordingly urges the authorities to implement the FSAP recommendations relating to the stock market and insurance sector. Staff recommends, in particular, an expeditious drafting and passing of the capital market and insurance laws; and establishing the capital market and insurance authorities to ensure comprehensive oversight of the stock exchange, investment companies, and the insurance sector. While the banking system appears to have the ability to withstand any reasonable market correction, there is scope for improved transparency 
through implementation of more comprehensive accounting standards for other financial and non-financial companies.

\section{Staff urges the authorities to cast structural reforms in the context of a} comprehensive strategy allowing for a broader private sector role, and to accelerate implementation of these reforms. This would lead to a much higher level of investment and generation of employment in the economy. The progress made in private sector participation in sectors previously dominated by the public sector is in the right direction. In the same spirit, staff encourages the authorities to expedite the updating of outdated laws and regulations to promote a more market-friendly environment, and to move to market-based pricing of electricity, petroleum products, and water. Staff urges the authorities to apply the Kuwaitization policy flexibly so that the competitiveness and profitability of the private sector are not adversely affected, and to intensify their efforts to raise the skills of the Kuwaiti labor force to meet the requirements of the private sector. Staff also encourages the authorities to consider positive incentive schemes rather than negative incentives to achieve Kuwaitization goals.

\section{Although the quality of economic data continues to improve, staff urges the} authorities for more timely dissemination of some key economic data, particularly on official websites. While Kuwait's data are adequate for surveillance purposes, the staff encourages the authorities to improve communications between the various government agencies to improve compilation of both the national income and balance of payments statistics. Coordination with other GCC countries to adopt common data standards across all sectors will also be a step toward establishing the convergence criteria for the planned monetary union. Fund technical assistance, perhaps on a GCC-wide basis, would be particularly beneficial.

34. It is recommended that the next Article IV consultation take place on the standard 12-month cycle. 
Table 1. Kuwait: Selected Economic Indicators, 2001-06

(Quota: SDR 1381.1 million)

(Population: 2.87 million, June 2005)

(Per capita GDP: \$26,020, 2005 estimate)

\begin{tabular}{|c|c|c|c|c|c|c|}
\hline & 2001 & 2002 & 2003 & 2004 & $\frac{\text { Est. }}{2005}$ & $\frac{\text { Proj. }}{2006}$ \\
\hline \multicolumn{7}{|l|}{ Oil and gas sector } \\
\hline Total oil and gas exports (in billions of U.S. dollars) & 15.0 & 14.1 & 19.6 & 27.8 & 42.1 & 51.1 \\
\hline Average oil export price (in U.S. dollar/barrel) & 21.2 & 22.9 & 25.5 & 31.6 & 45.7 & 51.5 \\
\hline Crude oil production (in millions of barrels/day) & 1.95 & 1.75 & 2.11 & 2.29 & 2.58 & 2.69 \\
\hline \multirow[t]{2}{*}{ Share of oil GDP in total GDP (in percent) } & 46.4 & 41.9 & 46.4 & 52.6 & 59.8 & 61.9 \\
\hline & \multicolumn{6}{|c|}{ (Annual percentage change, unless otherwise indicated) } \\
\hline \multicolumn{7}{|l|}{ National accounts and prices $1 /$} \\
\hline Nominal GDP (market prices, in billions of Kuwaiti dinar) & 10.7 & 11.6 & 13.8 & 16.4 & 21.8 & 25.2 \\
\hline Nominal GDP (market prices, in billions of U.S. dollars) & 34.9 & 38.1 & 46.2 & 55.7 & 74.6 & 86.3 \\
\hline Real GDP & 0.7 & 5.1 & 13.2 & 6.4 & 8.5 & 6.2 \\
\hline Real oil GDP & -3.3 & -7.9 & 19.8 & 7.7 & 11.3 & 5.2 \\
\hline Real non-oil GDP & 3.5 & 13.1 & 10.1 & 6.3 & 6.5 & 6.5 \\
\hline Real Gross Disposable Income (GDI) & -4.1 & 6.9 & 15.0 & 13.6 & 23.7 & 11.5 \\
\hline CPI inflation (average) & 1.4 & 0.8 & 1.0 & 1.3 & 3.9 & 3.5 \\
\hline \multirow[t]{2}{*}{ Unemployment rate (Kuwaiti nationals) 2/ } & 2.5 & 3.6 & 3.4 & 3.9 & 4.4 & $\ldots$ \\
\hline & \multicolumn{6}{|c|}{ (In percent of GDP at market prices) } \\
\hline \multicolumn{7}{|l|}{ Investment and savings } \\
\hline Investment & 14.3 & 17.1 & 14.6 & 14.2 & 15.7 & 14.3 \\
\hline Public & 3.6 & 4.3 & 4.4 & 4.0 & 3.4 & 3.2 \\
\hline Private $3 /$ & 10.7 & 12.8 & 10.2 & 10.2 & 12.4 & 11.0 \\
\hline Gross national savings & 38.2 & 28.2 & 35.0 & 48.1 & 58.9 & 63.3 \\
\hline Public & 23.5 & 25.4 & 24.1 & 32.3 & 46.8 & 47.6 \\
\hline Private $3 /$ & 14.7 & 2.8 & 10.9 & 15.8 & 12.2 & 15.7 \\
\hline \multirow[t]{2}{*}{ Savings/investment balance } & 23.9 & 11.2 & 20.4 & 33.9 & 43.2 & 49.1 \\
\hline & \multicolumn{6}{|c|}{ (In percent of GDP at market prices) } \\
\hline \multicolumn{7}{|l|}{ Budgetary operations 4/ } \\
\hline Revenue & 60.7 & 59.8 & 55.2 & 59.6 & 70.5 & 71.6 \\
\hline Oil & 41.4 & 45.3 & 42.6 & 46.0 & 55.9 & 56.3 \\
\hline Non-oil, of which: & 19.3 & 14.5 & 12.6 & 13.6 & 14.6 & 15.2 \\
\hline Investment income & 12.7 & 9.6 & 8.1 & 9.9 & 11.4 & 12.1 \\
\hline Expenditures and net lending & 43.9 & 40.3 & 37.8 & 35.2 & 30.1 & 28.5 \\
\hline Of which: current & 39.3 & 35.6 & 33.1 & 30.7 & 26.0 & 25.1 \\
\hline capital & 4.6 & 4.7 & 4.7 & 4.5 & 4.1 & 3.4 \\
\hline Balance & 16.8 & 19.5 & 17.4 & 24.4 & 40.4 & 43.0 \\
\hline Domestic financing & -1.2 & -2.9 & -0.8 & -6.1 & -1.9 & -2.7 \\
\hline External financing & -15.6 & -16.6 & -16.6 & -18.3 & -38.5 & -40.4 \\
\hline Non-oil primary balance (in percent of non-oil GDP) & -56.9 & -54.4 & -57.1 & -61.5 & -57.6 & -55.7 \\
\hline Total gross debt (calendar year-end) & 35.1 & 30.0 & 23.8 & 18.5 & 13.0 & 10.8 \\
\hline
\end{tabular}


Table 1. Kuwait: Selected Economic Indicators, 2001-06 (concluded)

\begin{tabular}{|c|c|c|c|c|c|c|}
\hline & 2001 & 2002 & 2003 & 2004 & $\frac{\text { Est. }}{2005}$ & $\frac{\text { Proj. }}{2006}$ \\
\hline & \multicolumn{6}{|c|}{ (Changes in percent of beginning broad money stock) } \\
\hline \multicolumn{7}{|l|}{ Money and credit } \\
\hline Net foreign assets $5 /$ & 6.5 & -4.1 & -4.8 & 10.3 & 5.9 & 4.8 \\
\hline Net domestic assets & 6.3 & 8.8 & 12.7 & 1.8 & 10.6 & 2.7 \\
\hline Claims on government (net) & -4.1 & 0.2 & -2.8 & -10.4 & -3.7 & -5.0 \\
\hline Claims on nongovernment sector & 11.1 & 10.5 & 17.2 & 14.5 & 14.2 & 8.3 \\
\hline Broad money & 12.8 & 4.8 & 7.8 & 12.1 & 16.4 & 7.5 \\
\hline Velocity of broad money & 1.2 & 1.2 & 1.3 & 1.4 & 1.6 & 1.7 \\
\hline Kuwaiti dinar 3-month deposit rate (average in percent) & 3.7 & 2.2 & 1.5 & 1.6 & 4.0 & $\ldots$ \\
\hline U.S. dollar 3-month deposit rate (average in percent) & 3.3 & 1.3 & 0.7 & 1.0 & 3.2 & $\ldots$ \\
\hline Stock market unweighted index (annual percent change) & 26.8 & 39.0 & 101.7 & 33.8 & 78.6 & $\ldots$ \\
\hline Stock market weighted index (annual percent change) & $\ldots$ & $\ldots$ & 69.3 & 15.3 & 67.4 & ... \\
\hline & \multicolumn{6}{|c|}{ (In millions of U.S. dollars, unless otherwise indicated) } \\
\hline External sector & & & & & & \\
\hline Exports of goods and services & 17,910 & 17,010 & 24,901 & 33,321 & 48,599 & 58,073 \\
\hline Of which: Oil and refined products & 14,977 & 14,057 & 19,567 & 27,764 & 42,132 & 51,051 \\
\hline Annual percentage change in volume & -0.4 & -12.1 & 30.9 & 5.8 & 8.3 & 5.9 \\
\hline Imports of goods and services & $-12,406$ & $-13,958$ & $-16,464$ & $-19,848$ & $-22,119$ & $-23,968$ \\
\hline Annual percentage change in volume & 7.0 & 6.9 & 13.0 & 10.1 & 6.5 & 6.5 \\
\hline Current account & 8,328 & 4,250 & 9,414 & 17,323 & 32,250 & 42,335 \\
\hline In percent of GDP 6/ & 23.9 & 11.2 & 20.4 & 31.1 & 43.2 & 49.1 \\
\hline External public and publicly guaranteed debt & 409 & 641 & 510 & 510 & $\ldots$ & $\ldots$ \\
\hline International reserve assets, of which: & 10,000 & 9,314 & 7,685 & 8,359 & 9,528 & 11,194 \\
\hline Central Bank of Kuwait & 9,268 & 8,455 & 6,744 & 7,451 & 8,688 & 10,354 \\
\hline In months of imports of goods and services & 9.7 & 8.0 & 5.6 & 5.1 & 5.2 & 5.6 \\
\hline \multicolumn{7}{|l|}{ Memorandum items: } \\
\hline Exchange rate (US\$ per KD, period average) & 3.26 & 3.29 & 3.36 & 3.39 & 3.42 & $\cdots$ \\
\hline Nominal effective exchange rate (NEER) $7 /$ & 5.8 & -0.7 & -6.9 & -4.2 & -0.8 & $\ldots$ \\
\hline Real effective exchange rate (REER) $7 /$ & 5.2 & -0.9 & -7.9 & -5.2 & 1.3 & $\ldots$ \\
\hline Credit rating $(\mathrm{S} \& \mathrm{P})$ & $\mathrm{A}+$ & $\mathrm{A}+$ & $\mathrm{A}+$ & $\mathrm{A}+$ & $\mathrm{A}+$ & $\cdots$ \\
\hline
\end{tabular}

Sources: Data provided by the authorities; and Fund staff estimates.

1/ GDP data for 2001 are not comparable with GDP data for 2002 and later years. While GDP data for 2001 are based on International Standard Industrial Classification (ISIC) Revision 2, data for 2002 and later years are based on ISIC Revision 3 which covers a wider number of variables and sectors.

2/ For 2005, end-June.

3/ Also includes government entities.

4/ Kuwaiti fiscal year ending March 31.

5/ Excludes SDRs and IMF reserve position.

6/ For 2004, the discrepancy between the savings/investment balance and the current account balance is possibly due to the data being preliminary and may be resolved when the authorities revise the data.

7/ For 2005, average for January to November. The NEER and REER appreciated by 9.2 and 11.7 percent during January-November 2005, respectively. 
Table 2. Kuwait: Summary of Government Finance, 2001/02-2005/06 1/

\begin{tabular}{|c|c|c|c|c|c|c|}
\hline & & & & Prel. & Budget & Proj. \\
\hline & $2001 / 02$ & $2002 / 03$ & 2003/04 & $2004 / 05$ & $2005 / 06$ & $2005 / 06$ \\
\hline Total revenue & 6,630 & 7,257 & 7,971 & 10,579 & 4,438 & 15,967 \\
\hline Oil and gas & 4,525 & 5,499 & 6,150 & 8,171 & 3,914 & 12,654 \\
\hline $\begin{array}{l}\text { Investment income and transfer } \\
\text { of profits of public entities } 2 /\end{array}$ & 1,386 & 1,165 & 1,166 & 1,753 & 0 & 2,586 \\
\hline Other current revenue 3 / & 718 & 567 & 618 & 595 & 499 & 661 \\
\hline Capital revenue & 1 & 26 & 37 & 60 & 25 & 67 \\
\hline Total expenditure & 4,795 & 4,890 & 5,454 & 6,252 & 7,063 & 6,823 \\
\hline Current & 4,289 & 4,318 & 4,773 & 5,450 & 5,901 & 5,884 \\
\hline Wages and salaries & 1,637 & 1,709 & 1,825 & 1,940 & 2,146 & 2,155 \\
\hline Goods and services & 1,061 & 1,196 & $1,436^{4 /}$ & 1,421 & 1,563 & 1,586 \\
\hline Interest on domestic debt 5/ & 203 & 121 & 81 & 86 & 37 & 82 \\
\hline Transfers abroad & 97 & 82 & 63 & 132 & 77 & 147 \\
\hline Subsidies and transfers $6 /$ & 1,292 & 1,210 & 1,368 & $1,871^{7 /}$ & 2,078 & 1,914 \\
\hline Capital & 506 & 572 & 681 & 802 & 1,162 & 939 \\
\hline Overall balance & 1,835 & 2,367 & 2,517 & 4,327 & $-2,625$ & 9,145 \\
\hline Overall balance exc. oil rev. & $-2,690$ & $-3,132$ & $-3,633$ & $-3,844$ & $-6,539$ & $-3,509$ \\
\hline Financing & $-1,835$ & $-2,367$ & $-2,517$ & $-4,327$ & 2,625 & $-9,145$ \\
\hline Domestic (net) & -134 & -351 & -122 & $-1,077$ & $\ldots$. & -426 \\
\hline Banks & -169 & -196 & -66 & $-1,077$ & $\ldots$. & -426 \\
\hline Nonbanks & 35 & -156 & -55 & 0 & $\ldots$. & 0 \\
\hline External & 0 & 0 & 0 & 0 & $\ldots$. & 0 \\
\hline Reserve funds $8 /$ & $-1,701$ & $-2,016$ & $-2,395$ & $-3,250$ & $\ldots$ & $-8,718$ \\
\hline & & & (In perc & ent of GDP) & & \\
\hline Revenue & 60.7 & 59.8 & 55.2 & 59.6 & 19.6 & 70.5 \\
\hline Oil and gas & 41.4 & 45.3 & 42.6 & 46.0 & 17.3 & 55.9 \\
\hline Investment income & 12.7 & 9.6 & 8.1 & 9.9 & 0.0 & 11.4 \\
\hline Other current revenue 3/ & 6.6 & 4.7 & 4.3 & 3.4 & 2.2 & 2.9 \\
\hline Expenditure & 43.9 & 40.3 & 37.8 & 35.2 & 31.2 & 30.1 \\
\hline Current & 39.3 & 35.6 & 33.1 & 30.7 & 26.1 & 26.0 \\
\hline Wages and salaries & 15.0 & 14.1 & 12.6 & 10.9 & 9.5 & 9.5 \\
\hline Goods and noninterest services & 9.7 & 9.9 & 10.0 & 8.0 & 6.9 & 7.0 \\
\hline Interest on domestic and foreign debt & 1.9 & 1.0 & 0.6 & 0.5 & $\ldots$ & 0.4 \\
\hline Subsidies and transfers & 11.8 & 10.0 & 9.5 & 10.5 & $\ldots$ & 8.5 \\
\hline Capital & 4.6 & 4.7 & 4.7 & 4.5 & 5.1 & 4.1 \\
\hline Overall balance & 16.8 & 19.5 & 17.4 & 24.4 & -11.6 & 40.4 \\
\hline Non-oil deficit/Non-oil GDP & -44.9 & -45.4 & -48.5 & -47.9 & -70.5 & -39.2 \\
\hline Non-oil primary deficit/Non-oil GDP & -56.9 & -54.4 & -57.1 & -61.5 & $\ldots$ & -57.6 \\
\hline Memorandum items: & (In & nillions of & Kuwaiti din & ars, unless ot & erwise indic & ed) \\
\hline Overall balance (excluding investment & & & & & & \\
\hline income and profit transfers) & 449 & 1,202 & 1,351 & 2,573 & -2625 & 6,559 \\
\hline (In percent of GDP) & 4.1 & 9.9 & 9.4 & 14.5 & -11.6 & 29.0 \\
\hline Average oil export price (in US dollar/barrel) & 21.6 & 23.5 & 27.1 & 35.2 & 21.0 & 47.2 \\
\hline
\end{tabular}

Sources: Ministry of Finance; Central Bank of Kuwait; and Fund staff estimates and projections.

1/ Coverage of budgetary operations includes the operation of the KIA. Data are on an accrual basis.

2/ Excluded from the national budget presentation. Estimated by the Fund staff.

3/ Excludes revenues from utility tariffs (which are included in the national budget presentation), but includes UN (Iraq) compensations.

4/ Includes the KD 121 million supplementary budget for the emergency spending.

5/ Covers interest payments on the treasury bills and bonds, and on the DCP bonds. Only the latter is included in the national budget presentation.

6/ A breakdown of the relative share of subsidies and transfers is provided in Table 17 of the Statistical Appendix.

7/ Includes KD 192 million one-time transfer of the oil windfall to Kuwaiti nationals.

8/ The Reserve Fund for Future Generations (RFFG) and the General Reserve Fund (GRF). 
Table 3. Kuwait: Summary Balance of Payments, 2001-10

(In millions of U.S. dollars)

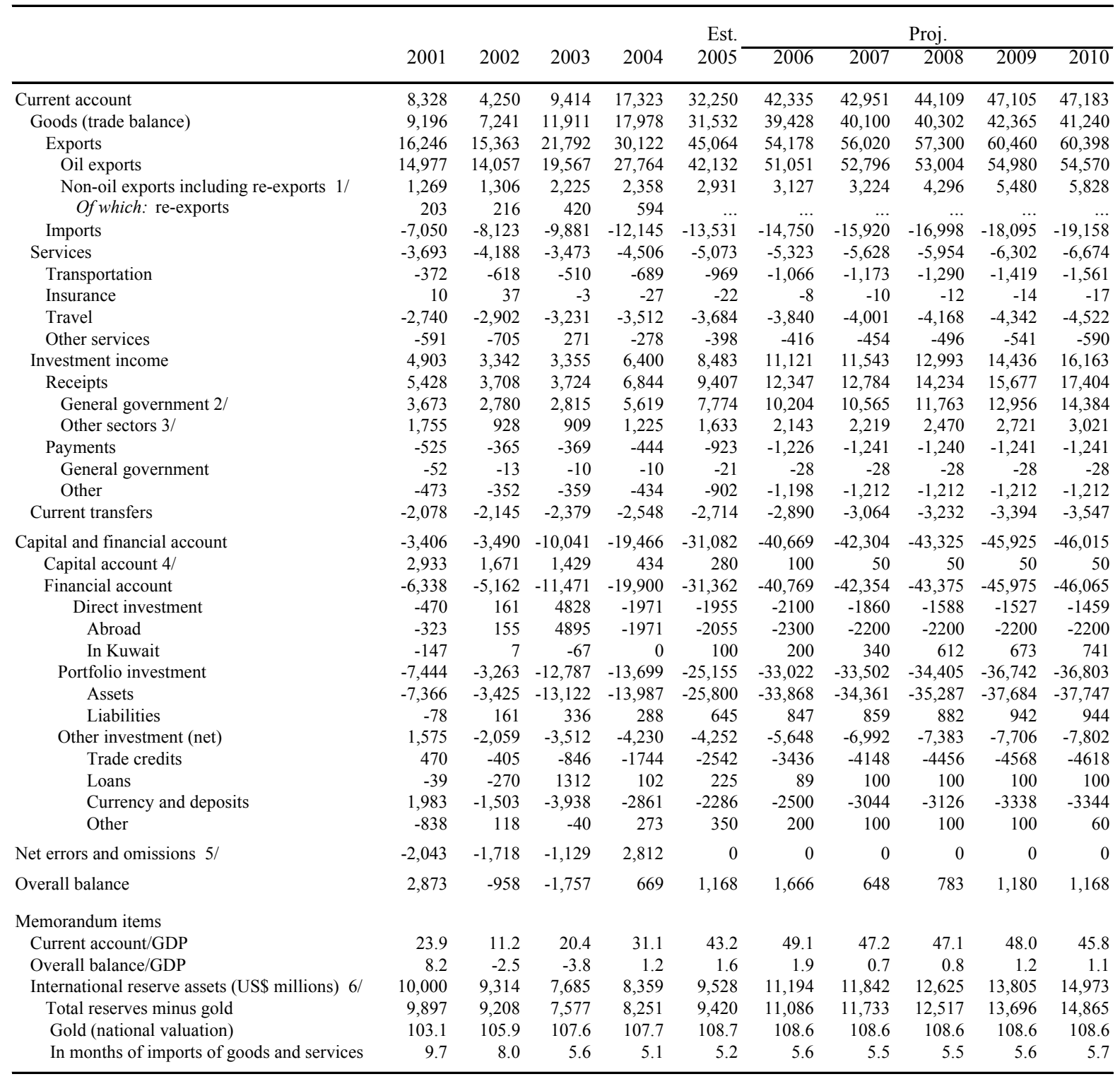

Sources: Central Bank of Kuwait; and Fund staff estimates.

$1 /$ Also includes unrecorded exports.

2/ Kuwait Investment Authority, Kuwait Petroleum Corporation, Kuwait Fund for Arab Economic Development,

Public Institute for Social Security, Kuwait Airways Corporation, and Bank of Savings and Credit.

3/ CBK, local banks, investment companies, exchange companies, insurance companies, and the

nonfinancial private sector.

4/ Includes UN war compensation.

5/ Includes other unclassified private sector flows.

6/ Includes SDRs and IMF reserve position. 
Table 4. Kuwait: Monetary Survey, 2000-06

\begin{tabular}{|c|c|c|c|c|c|c|c|}
\hline \multirow[b]{2}{*}{ End of period } & & & & & & Est. & Proj. \\
\hline & 2000 & 2001 & 2002 & 2003 & 2004 & 2005 & 2006 \\
\hline & \multicolumn{7}{|c|}{ (In millions of Kuwaiti dinars) } \\
\hline Foreign assets (net) $1 /$ & 2,778 & 3,306 & 2,930 & 2,464 & 3,535 & 4,218 & 4,871 \\
\hline Central bank & 2,005 & 2,850 & 2,521 & 1,966 & 2,165 & 2,497 & 2,983 \\
\hline Local banks & 773 & 456 & 409 & 497 & 1,370 & 1,721 & 1,888 \\
\hline Domestic assets (net) & 5,385 & 5,902 & 6,716 & 7,938 & 8,120 & 9,353 & 9,717 \\
\hline Claims on government (net) & 2,911 & 2,573 & 2,595 & 2,323 & 1,246 & 820 & 140 \\
\hline Central bank (net) & -532 & -598 & -354 & -413 & -662 & -796 & $-1,055$ \\
\hline Claims & 0 & 0 & 0 & 0 & 0 & 0 & 0 \\
\hline Deposits & 532 & 598 & 354 & 413 & 662 & 796 & 1,055 \\
\hline Local banks (net) & 3,443 & 3,171 & 2,949 & 2,735 & 1,908 & 1,616 & 1,195 \\
\hline Claims & 3,628 & 3,402 & 3,248 & 3,051 & 2,750 & 2,547 & 2,431 \\
\hline Government debt bonds & 1,491 & 1,294 & 1,006 & 818 & 604 & 445 & 328 \\
\hline Public debt instruments & 2,137 & 2,108 & 2,242 & 2,232 & 2,146 & 2,102 & 2,102 \\
\hline Other claims & 0 & 0 & 0 & 0 & 0 & 0 & 0 \\
\hline Deposits & 185 & 231 & 299 & 315 & 842 & 932 & 1,235 \\
\hline Claims on nongovernment sector & 5,848 & 6,753 & 7,723 & 9,379 & 10,886 & 12,546 & 13,676 \\
\hline Credit facilities & 5,230 & 6,027 & 6,854 & 8,419 & 9,867 & 11,501 & 12,537 \\
\hline Local investments & 619 & 726 & 870 & 959 & 1,019 & 1,044 & 1,138 \\
\hline Other items (net) & $-3,375$ & $-3,423$ & $-3,602$ & $-3,764$ & $-4,011$ & $-4,012$ & $-4,099$ \\
\hline Broad money & 8,163 & 9,209 & 9,646 & 10,401 & 11,655 & 13,571 & 14,588 \\
\hline Money & 1,468 & 1,641 & 2,067 & 2,612 & 3,174 & 3,831 & 4,134 \\
\hline Quasi money & 6,695 & 7,567 & 7,580 & 7,790 & 8,481 & 9,740 & 10,453 \\
\hline \multirow[t]{2}{*}{ Of which: Foreign currency deposits } & 895 & 892 & 904 & 991 & 1,169 & 1,704 & 1,829 \\
\hline & \multicolumn{7}{|c|}{ (Annual percentage change) } \\
\hline Foreign assets (net) & 46.3 & 19.0 & -11.4 & -15.9 & 43.5 & 19.3 & 15.5 \\
\hline Central Bank & 51.9 & 42.2 & -11.6 & -22.0 & 10.1 & 15.3 & 19.5 \\
\hline Local banks & 33.6 & -41.0 & -10.3 & 21.5 & 175.4 & 25.6 & 9.7 \\
\hline Domestic assets (net) & -6.8 & 9.6 & 13.8 & 18.2 & 2.3 & 15.2 & 3.9 \\
\hline Claims on Government (net) & -16.2 & -11.6 & 0.8 & -10.5 & -46.4 & -34.2 & -82.9 \\
\hline Claims on nongovernment sector & 5.4 & 15.5 & 14.4 & 21.4 & 16.1 & 15.2 & 9.0 \\
\hline Other items (net) & -4.0 & -1.4 & -5.2 & -4.5 & -6.6 & 0.0 & -2.2 \\
\hline Broad money & 6.3 & 12.8 & 4.8 & 7.8 & 12.1 & 16.4 & 7.5 \\
\hline Money & 7.0 & 11.8 & 25.9 & 26.4 & 21.6 & 20.7 & 7.9 \\
\hline Quasi money & 6.2 & 13.0 & 0.2 & 2.8 & 8.9 & 14.8 & 7.3 \\
\hline \multirow[t]{2}{*}{ Of which: Foreign currency deposits } & 1.6 & -0.3 & 1.3 & 9.6 & 18.0 & 45.8 & 7.3 \\
\hline & \multicolumn{7}{|c|}{ (Change in percent of beginning broad money stock) } \\
\hline Foreign assets (net) & 11.5 & 6.5 & -4.1 & -4.8 & 10.3 & 5.9 & 4.8 \\
\hline Central bank & 8.9 & 10.4 & -3.6 & -5.7 & 1.9 & 2.8 & 3.6 \\
\hline Local banks & 2.5 & -3.9 & -0.5 & 0.9 & 8.4 & 3.0 & 1.2 \\
\hline Domestic assets (net) & -5.1 & 6.3 & 8.8 & 12.7 & 1.8 & 10.6 & 2.7 \\
\hline Claims on government (net) & -7.3 & -4.1 & 0.2 & -2.8 & -10.4 & -3.7 & -5.0 \\
\hline Claims on nongovernment sector & 3.9 & 11.1 & 10.5 & 17.2 & 14.5 & 14.2 & 8.3 \\
\hline Other items (net) & -1.7 & -0.6 & -1.9 & -1.7 & -2.4 & 0.0 & -0.6 \\
\hline Broad money & 6.3 & 12.8 & 4.8 & 7.8 & 12.1 & 16.4 & 7.5 \\
\hline Money & 1.3 & 2.1 & 4.6 & 5.6 & 5.4 & 5.6 & 2.2 \\
\hline Quasi money & 5.1 & 10.7 & 0.1 & 2.2 & 6.6 & 10.8 & 5.3 \\
\hline Of which: Foreign currency deposits & 0.2 & 0.0 & 0.1 & 0.9 & 1.7 & 4.6 & 0.9 \\
\hline \multicolumn{8}{|l|}{ Memorandum items: } \\
\hline Net domestic credit (annual percentage change) & -3.0 & 6.5 & 10.6 & 13.4 & 3.7 & 10.2 & 3.4 \\
\hline
\end{tabular}

Sources: Central Bank of Kuwait; and Fund staff estimates.

1/ Excludes SDRs and IMF reserve position. 
Table 5. Kuwait: Selected Economic Indicators and Illustrative Baseline Scenario, 2001-10

(In percent of GDP, unless otherwise specified)

\begin{tabular}{|c|c|c|c|c|c|c|c|c|c|c|}
\hline & & & & Prov. & Est. & & Baselir & ne Scena & ario & \\
\hline & 2001 & 2002 & 2003 & 2004 & 2005 & 2006 & 2007 & 2008 & 2009 & 2010 \\
\hline Production and prices $1 /$ & & & & & & & & & & \\
\hline Nominal GDP (KD millions) & 10,700 & 11,585 & 13,768 & 16,420 & 21,783 & 25,191 & 26,555 & 27,346 & 28,667 & 30,052 \\
\hline Nominal GDP (percent change) & -7.5 & 8.3 & 18.8 & 19.3 & 32.7 & 15.6 & 5.4 & 3.0 & 4.8 & 4.8 \\
\hline Nominal non-oil GDP (percent change) & 3.9 & 17.3 & 9.7 & 5.5 & 12.4 & 9.7 & 8.5 & 7.2 & 6.8 & 6.8 \\
\hline Real GDP (percent change) & 0.7 & 5.1 & 13.2 & 6.4 & 8.5 & 6.2 & 4.7 & 5.2 & 5.4 & 3.3 \\
\hline Real oil GDP (percent change) & -3.3 & -7.9 & 19.8 & 7.7 & 11.3 & 5.2 & 2.0 & 4.3 & 5.7 & 1.0 \\
\hline Real non-oil GDP (percent change) & 3.5 & 13.1 & 10.1 & 6.3 & 6.5 & 6.5 & 6.0 & 5.5 & 5.0 & 4.5 \\
\hline Kuwait crude export price (US\$ per barrel) & 21.2 & 22.9 & 25.5 & 31.6 & 45.7 & 51.5 & 52.3 & 50.3 & 49.3 & 48.5 \\
\hline Crude oil output (millions of barrels per day) & 1.95 & 1.75 & 2.11 & 2.29 & 2.58 & 2.69 & 2.74 & 2.85 & 3.02 & 3.05 \\
\hline Consumer price index (percent change) & 1.4 & 0.8 & 1.0 & 1.3 & 3.9 & 3.5 & 3.0 & 2.0 & 1.9 & 1.8 \\
\hline Public finance 2/ & & & & & & & & & & \\
\hline Revenue, of which: & 60.7 & 59.8 & 55.2 & 59.6 & 70.5 & 71.6 & 70.6 & 70.2 & 69.8 & 67.8 \\
\hline Oil and gas & 41.4 & 45.3 & 42.6 & 46.0 & 55.9 & 56.3 & 55.2 & 53.8 & 52.7 & 50.0 \\
\hline Investment income 3/ & 12.7 & 9.6 & 8.1 & 9.9 & 11.4 & 12.1 & 12.3 & 13.1 & 13.7 & 14.3 \\
\hline Expenditure & 43.9 & 40.3 & 37.8 & 35.2 & 30.1 & 28.5 & 28.9 & 29.3 & 29.5 & 29.6 \\
\hline Current & 39.3 & 35.6 & 33.1 & 30.7 & 26.0 & 25.1 & 25.3 & 25.7 & 25.7 & 25.8 \\
\hline Capital & 4.6 & 4.7 & 4.7 & 4.5 & 4.1 & 3.4 & 3.6 & 3.7 & 3.8 & 3.8 \\
\hline Fiscal balance (deficit -) & 16.8 & 19.5 & 17.4 & 24.4 & 40.4 & 43.0 & 41.8 & 40.8 & 40.3 & 38.2 \\
\hline Fiscal balance excluding investment incol & 4.1 & 9.9 & 9.4 & 14.5 & 29.0 & 30.9 & 29.5 & 27.8 & 26.6 & 23.9 \\
\hline Non-oil fiscal balance (in percent of non-oil GDP) & -44.9 & -45.4 & -48.5 & -47.9 & -39.2 & -34.7 & -33.8 & -31.6 & -29.6 & -27.8 \\
\hline Balance of payments & & & & & & & & & & \\
\hline Exports of goods and services excl. re-exports & 49.4 & 42.8 & 50.8 & 56.2 & 61.8 & 64.2 & 63.2 & 63.2 & 63.8 & 58.7 \\
\hline Of which: 0 & 42.9 & 36.9 & 42.4 & 49.8 & 56.5 & 59.2 & 58.1 & 56.6 & 56.0 & 53.0 \\
\hline Imports of goods and services excl. re-exports & -33.7 & -34.8 & -32.6 & -32.0 & -26.3 & -24.7 & -25.3 & -26.5 & -27.1 & -18.6 \\
\hline Investment income (net) & 14.1 & 8.8 & 7.3 & 11.5 & 11.4 & 12.9 & 12.7 & 13.9 & 14.7 & 15.7 \\
\hline Current account & 23.9 & 11.2 & 20.4 & 31.1 & 43.2 & 49.1 & 47.2 & 47.1 & 48.0 & 45.8 \\
\hline Savin & & & & & & & & & & \\
\hline Final co & 69.9 & 74.9 & 67.1 & 58.8 & 48.8 & 46.2 & 47.9 & 49.8 & 50.1 & 53.8 \\
\hline Government & 23.6 & 25.3 & 23.8 & 21.0 & 16.7 & 15.7 & 15.9 & 16.3 & 16.5 & 16.7 \\
\hline Private 4/ & 46.3 & 49.6 & 43.3 & 37.8 & 32.0 & 30.5 & 32.0 & 33.5 & 33.6 & 37.2 \\
\hline Gross domestic investment & 14.3 & 17.1 & 14.6 & 14.2 & 15.7 & 14.3 & 14.2 & 13.5 & 13.1 & 12.6 \\
\hline Government & 3.6 & 4.3 & 4.4 & 4.0 & 3.4 & 3.2 & 3.3 & 3.5 & 3.5 & 3.6 \\
\hline Private 4/ & 10.7 & 12.8 & 10.2 & 10.2 & 12.4 & 11.0 & 10.9 & 10.1 & 9.6 & 9.0 \\
\hline Savings & 38.2 & 28.2 & 35.0 & 48.1 & 58.9 & 63.3 & 61.4 & 60.6 & 61.1 & 58.5 \\
\hline Government & 23.5 & 25.4 & 24.1 & 32.3 & 46.8 & 47.6 & 46.0 & 45.3 & 44.9 & 42.8 \\
\hline Private 4/ & 14.7 & 2.8 & 10.9 & 15.8 & 12.2 & 15.7 & 15.4 & 15.3 & 16.2 & 15.6 \\
\hline
\end{tabular}

Sources: Kuwait authorities; IMF World Economic Outlook, and Fund staff estimates.

1/ GDP data for 2001 are not comparable with GDP data for 2002 and later years. While GDP data for 2001 are based on International Standard Industrial Classification (ISIC) Revision 2, data for 2002 and later years are based on ISIC Revision 3 which covers a wider number of variables and sectors.

2/ Kuwaiti fiscal year ending March 31.

$3 /$ Includes profits of public enterprises.

4/ Also includes government entities. 
Table 6. Kuwait: Financial Soundness and Other Vulnerability Indicators, 2001-05

(In percent, unless otherwise indicated)

\begin{tabular}{|c|c|c|c|c|c|}
\hline & 2001 & 2002 & 2003 & 2004 & $\frac{\text { Est. }}{2005}$ \\
\hline \multicolumn{6}{|l|}{ Core Financial Soundness Indicators } \\
\hline Banks risk-weighted capital-asset ratio 1/ & 22.0 & 19.7 & 18.4 & 17.2 & 17.3 \\
\hline Nonperforming loans net of provisions to capital $1 /$ & 22.7 & 14.1 & 7.2 & 5.9 & 0.8 \\
\hline $\begin{array}{l}\text { Ratio of banks' nonperforming loans to total loans } 1 / \\
\text { Of which: }\end{array}$ & 10.3 & 7.8 & 6.1 & 5.5 & 4.5 \\
\hline Nonperforming loans from before invasion $1 /$ & 5.1 & 4.8 & 3.6 & 2.9 & 2.4 \\
\hline Nonperforming loans since liberation $1 /$ & 5.2 & 3.0 & 2.5 & 2.6 & 2.1 \\
\hline \multicolumn{6}{|l|}{ Ratio of bank lending to total domestic credit facilities } \\
\hline Stock market-related $1 / 2 /$ & 6.4 & 5.8 & 9.0 & 8.5 & 9.3 \\
\hline Real estate $1 / 3 /$ & 19.3 & 18.9 & 17.0 & 16.4 & 21.9 \\
\hline Total (stock market, real estate) $1 /$ & 25.7 & 24.8 & 26.0 & 24.9 & 31.2 \\
\hline Return on assets $1 /$ & 2.0 & 1.8 & 2.0 & 2.5 & 3.2 \\
\hline Return on equity $1 /$ & 18.2 & 17.4 & 18.6 & 22.4 & 25.7 \\
\hline Banks' liquidity ratio $4 /$ & 24.1 & 21.0 & 14.8 & 13.2 & 12.5 \\
\hline Liquid assets to short-term liabilities 5/ & 133.1 & 86.4 & 52.3 & 52.0 & 52.0 \\
\hline Net open position in foreign exchange to capital $1 /$ & -2.1 & 4.2 & 4.2 & 9.5 & 3.0 \\
\hline \multicolumn{6}{|l|}{ Other Financial Soundness Indicators } \\
\hline Banks' capital-asset ratio & 11.2 & 10.4 & 10.7 & 12.1 & 12.6 \\
\hline Banks' leverage $6 /$ & 9.0 & 9.6 & 9.4 & 8.3 & 8.0 \\
\hline Investment companies' capital and reserve/total assets $1 / 7 /$ & 31.5 & 31.2 & 30.3 & 30.3 & 32.3 \\
\hline Loan provisions as a proportion of nonperforming loans $1 /$ & 53.4 & 64.3 & 77.7 & 83.2 & 97.2 \\
\hline \multicolumn{6}{|l|}{ Ratio of bank lending to banks' own funds $1 /$} \\
\hline Stock market-related $1 / 2 /$ & 22.9 & 22.5 & 37.6 & 36.0 & 40.5 \\
\hline Real estate $1 / 3 /$ & 69.3 & 73.3 & 71.4 & 69.5 & 120.9 \\
\hline Total (stock market and real estate) $1 /$ & 92.2 & 95.8 & 109.0 & 105.5 & 161.4 \\
\hline Increase in net bank profits $1 /$ & 9.9 & 0.6 & 21.2 & 27.5 & 3.2 \\
\hline Ratio of net profits to total bank assets $1 /$ & 2.0 & 1.8 & 2.0 & 2.5 & 25.7 \\
\hline Ratio of net profits to total shareholders' equity $1 /$ & 18.2 & 17.4 & 18.6 & 22.4 & 49.1 \\
\hline \multirow[t]{2}{*}{ Banks' interest rate spread 8/ } & 0.4 & 0.9 & 0.8 & 0.5 & 0.8 \\
\hline & \multicolumn{5}{|c|}{ (In millions of Kuwaiti dinars) } \\
\hline Net foreign assets of local banks & 456.1 & 409.3 & 497.3 & $1,369.8$ & $1,720.8$ \\
\hline Net foreign assets of investment companies $7 / 9 /$ & 667.1 & 708.3 & 899.6 & $1,045.3$ & $1,222.4$ \\
\hline Open foreign exchange position of banks $1 / 10 /$ & -34.9 & 74.6 & 84.9 & 210.6 & 84.7 \\
\hline
\end{tabular}


Table 6. Kuwait: Financial Soundness and Other Vulnerability Indicators, 2001-05 (concluded)

(In percent, unless otherwise indicated)

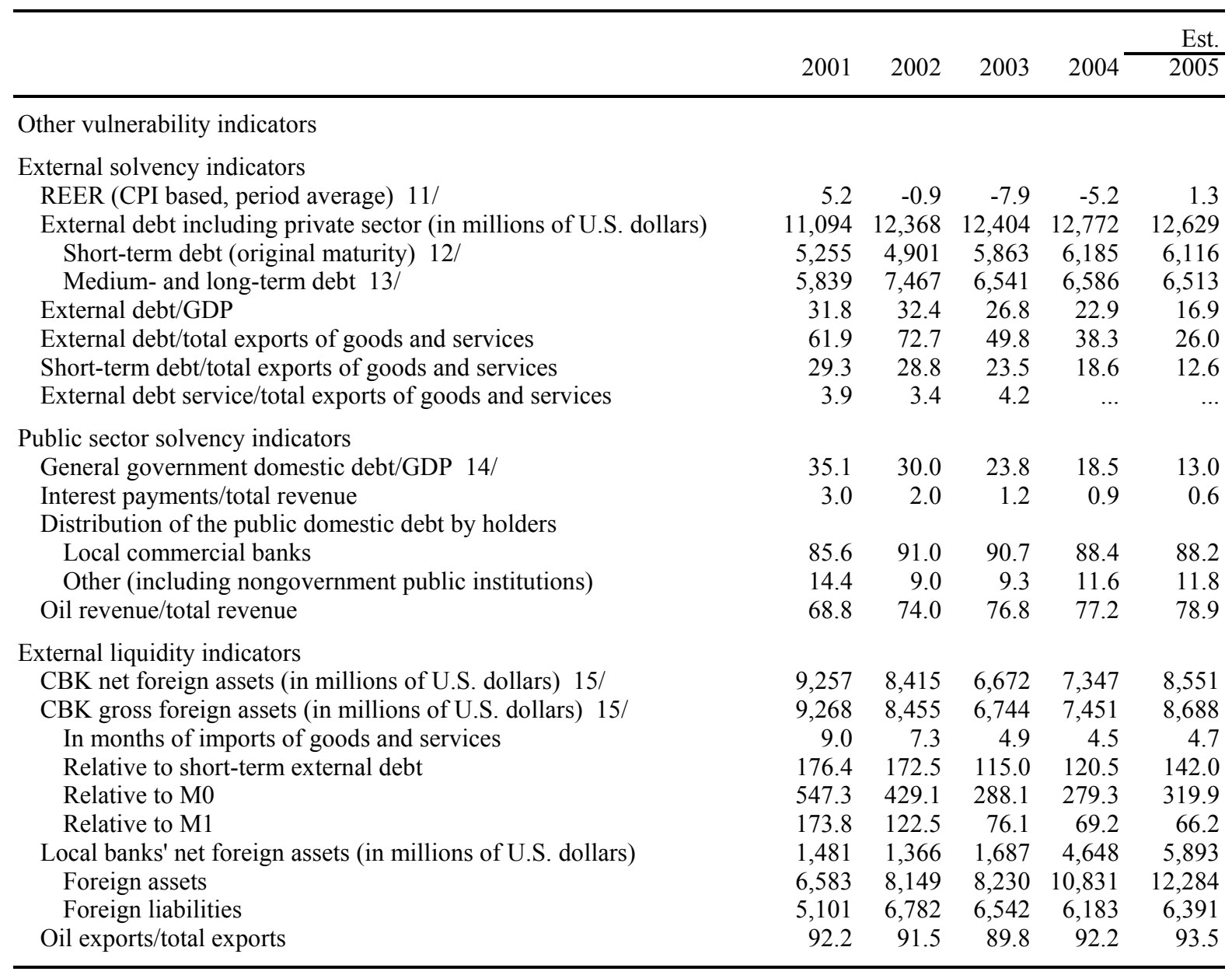

Sources: Central Bank of Kuwait, and Fund staff estimates.

$1 / 2005$ data are as of end-September.

2/ Includes lending for stock purchases of listed and unlisted domestic and foreign companies .

3 / Includes only credit to developers (excludes credit to home buyers). Ratios may be overestimated due to problems with loan classification by the local banks.

4/ Ratio of liquid assets (cash, central bank current deposits, and treasury bills and bonds) to total assets.

5/ Liquid assets on short-term liabilities (demand, government, and interbank deposits).

6/ Ratio of total liabilities to banks' own funds (in times).

7/ Includes only non-Islamic financial companies.

8/ Calculated as the difference between 3-month deposit rates in KD relative to 3-month deposit rates in US\$.

9/ Equals nonresident assets minus nonresident liabilities, excluding own funds.

10/ A (-) sign indicates a short position.

$11 / 2005$ data is the average for January to November.

12/ Short-term data are obtained from the joint BIS-IMF-OECD-World Bank database.

13/ Medium- and long-term debt is estimated as a residual.

14/ Treasury bills and bonds, and debt purchase bonds.

15/ Excludes SDRs and IMF reserve position. 


\section{FUND RELATIONS}

(As of January 31, 2006)

I. Membership Status: Joined September 13, 1962

Article VIII on April 5, 1963

II. General Resources Account:

SDR Million

Quota

$1,381.10$

\% Quota

Fund holdings of currency

$1,210.30$

100.00

Reserve position in Fund

170.82

87.63

12.37

III. SDR Department:

SDR Million

26.74

$\%$ Allocation

Net cumulative allocation

128.70

100.00

Holdings

481.21

IV. Outstanding Purchases and Loans: None

V. Financial Arrangements: None

VI. Projected Obligations to Fund: None

\section{Exchange Rate Arrangement:}

Since January 1, 2003, the Kuwaiti dinar has been pegged to the U.S. dollar with a margin of 3.5 percent on either side around the parity exchange rate of 299.63 fils/U.S. dollar. The decision to peg the dinar to the U.S. dollar reflected plans to create a single currency for the six members of the Cooperation Council for the Arab States of the Gulf (GCC). Previously, the Kuwaiti dinar was pegged to a U.S. dollar-dominated basket of currencies. On April 2, 2002 Kuwait notified the Fund, under Decision 144-(52/51), of exchange restrictions it introduced in order to implement UN Security Council resolutions 1373 (2001), 1333 (2000) and 1267 (1999).

\section{Article IV Consultations:}

The last Article IV consultation was completed by the Executive Board on April 25, 2005. The staff report and the associated Selected Issues and Statistical Appendix were published on the Fund's external website in July 2005, Country Report Nos. 05/231 and 05/234, respectively. 


\section{FSAP Participation}

A FSAP exercise was conducted in September 2003 in order to assess three international standards and codes (banking, securities, and AML/CFT). A FSSA report was discussed by the Executive Board along with the staff report for the 2003 Article IV consultation and was issued in May 2004, Country Report No. 04/151.

\section{Technical Assistance:}

STA Seminar on GDDS

STA National Accounts and Price Statistics

FAD Restructuring Budget Processes

FAD A Program for Tax Reform

MFD/LEG Bank Insolvency
February 2000

June 2001-June 2002

January/February 2002

December 2002

October 2004

\section{Resident Representative: None}

XII. Kuwait has consented to the quota increase under the Eleventh General Review of Quotas; it has accepted the Fourth Amendment of the Articles of Agreement. 


\title{
KUWAIT
}

\section{RELATIONS WITH THE WORLD BANK GROUP}

\author{
(As of January 18, 2006)
}

In February 2005, the Ministry of Finance renewed Kuwait's commitment to continue the TCP for another two years, effective January 1, 2005.

\section{Activities Completed and Ongoing During FY 2006}

- $\quad$ Review of the Offset Program: Based on government request, World Bank staff conducted a review of the offset program in early May 2005, and presented its findings and conclusions in June 05.

- Kuwait Petroleum Company (KPC): Bank responded to a request for assistance in privatization. Phase I of the project consists of analyzing privatization schemes for an independent hydrocarbon regulatory institution. Final report was submitted in early January 2006 and a presentation on findings will be made to officials end of January.

- Competition Law-Policy: Following up on a previous Bank report, a Project Concept Note was submitted in October 2005 for the implementation strategy. Revisions to incorporate comments received are underway. A mission to kick-off project is scheduled for mid-February 2006.

- $\quad$ MOF - Purchasing System Department: In May 2005, MNATC received a request to streamline the government purchasing/procurement systems. A draft proposal was sent on September 1, 2005. Clarifications sought by client. Response delivered. Waiting for authorities' decision.

- Labor Market, Education and Training (LABET): A World Bank team visited Kuwait and a draft proposal was submitted in August 2005. In the meantime, client had some inquiries which were responded to. Waiting for decision of authorities.

- $\quad$ Redesigning Business Registration Processes: Following up on a previous study on administrative barriers to investment, World Bank staff developed a concept note for implementation of the recommendations. A revised Concept Note was sent on January 11, 2006. Authorities agreed to the Concept Note and a mission is currently visiting Kuwait.

- Tax Reform Program: The World Bank was requested to provide a report on tax reform, including income, corporate taxes, and VAT. A presentation was made to the Minister of Finance during the Annual Meetings 2005, in collaboration with an IMF team. 
- Public Private Partnership: In October 2005, the World Bank submitted a draft proposal for PPP law. Law and bylaws were finalized end of December 2005 and are currently being translated into Arabic. The guidelines are being finalized and translated.

- Education Sector Reform/Education Indicators and Assessment Project:

Following the completion of "Education Expenditure Analysis" study, the World Bank continues to provide assistance in implementing the recommendations. This is a six-year program and we are in the third year.

- $\quad$ Education Workshop: World Bank conducted a workshop on education reform. Participants included the Minister of Education, undersecretary, assistant undersecretaries, heads of divisions, and representatives from the academia. This took place in the headquarter on July 6-12.

- $\quad 7^{\text {th }}$ Gulf Water Conference: World Bank will provide two keynote speakers at a regional water conference on November 19-23, 2005. 


\section{KUWAIT: STATISTICAL ISSUES}

Kuwait's data are adequate for surveillance, but there is scope for improved compilation of the national accounts and balance of payments statistics through better coordination between statistical agencies.

\section{National Accounts and Production}

The Central Statistical Office (CSO) has prepared estimates of GDP at both current and constant prices through 2003 (the 2003 estimates are still provisional). Recent improvements of national accounts include: change of the base year for the constant price data to 2000 and the estimates of value added for subsidized goods and services of the public utilities sector through the use of input costs (the household expenditure survey was used previously). The estimates of GDP have been published on the Central Statistical Office website. Starting from the final 2002 data, further improvements are planned for national accounts reflecting the adoption of the $1993 S N A$, a sampling frame based on the establishment survey (2002), and the expansion of the coverage of questionnaires. Continued progress, especially in the estimation of value added for the oil sector, requires the dedication of adequate resources and improved coordination between the Ministries of Planning, Oil, and Finance. STA has provided technical assistance to the Ministry of Planning to improve national accounts and price data. A resident statistics expert was attached to the Ministry of Planning from June 2001 to June 2002. It would be useful if the Central Bank of Kuwait (CBK) would publish oil sector information in the Quarterly Statistical Bulletin pertaining to output, refining, domestic consumption, export price for crude and refined products and the domestic price of petroleum products. These data are available from the Ministry of Oil.

\section{Price Statistics}

The weights are based on the household expenditure survey undertaken for 1999/2000 and were introduced into the index for a reference year of $2002=100$. An improved monthly CPI based on a revised basket has been published in monthly CPI bulletins with about a one-month lag. The wholesale price index (WPI) needs to be developed into a producer price index (PPI), to include all domestically produced goods, ex-factory, for the export and the domestic market, and, moreover, to be consistent with needs of national accounts. Timely and comprehensive labor force data are not available

\section{Government Finance Statistics}

Kuwait reports annual GFS data for publication in the Government Finance Statistics Yearbook (GFSY) and monthly government finance data for publication in IFS. The major components of its extrabudgetary revenues (investment income and transfers of profits of public institutions), extrabudgetary expenditures (interest on foreign debt and treasury paper), and financing operations conducted by two reserve funds are not reported. Data on investment income, and on interest on foreign debt and treasury paper, however, are usually provided to Article IV consultation missions. The authorities have made some progress in 
fiscal data presentation, but the lack of a suitable classification of data on the execution of the budget remains a constraint on monitoring effectively fiscal developments during the year. Moreover, data on the operations of the Public Institute for Social Security are not made available. Much of the weaknesses in the fiscal accounts stem from the limitations on the sharing of information between various government agencies. STA has indicated to the authorities that operations of the two reserve funds should be classified as part of government as they perform activities for public policy purposes (management of debt and assets, and financing of the budget). The authorities have also been briefed on the IMF's ongoing work to enhance the transparency of fiscal accounts and presentations detailed in the "Code of Good Practices on Fiscal Transparency" and were encouraged to adopt some of the practices recommended in the Code. According to the FAD report "Restructuring Budget Processes" finalized in March 2002, the weakest part of the Kuwaiti Public Expenditure Management (PEM) system is the accounting system.

\section{Money and Banking Statistics}

Money and banking data are reported on a regular and timely basis.

\section{Balance of Payments Statistics}

Kuwait's balance of payments data have substantially improved, in both coverage and methodology. Since the beginning of 1997, the CBK has compiled and disseminated detailed annual data in accordance with the methodology of the BPM5. Quarterly balance of payments and an annual statement of Kuwait's international investment position (IIP) have also been compiled since 1997 by the CBK and provided to Article IV consultation missions. Partial IIP data submitted to STA exclude foreign assets of other government agencies. They are not published by STA as the data are not reported in the prescribed format to facilitate the internationally accepted presentation. .Data on capital flows of the nonfinancial private sector (including foreign direct investment abroad and portfolio investment abroad) are currently not being compiled but measures are being taken (including collaboration between the CBK and the Tax Department of the Ministry of Finance) to correct this omission (which has contributed to the "errors and omissions" item). Enhancements have been made in the estimation of travel services, but further improvements are needed in compilation practices and in the estimation of data on several service items and private transfers. During discussions in October 2004, STA recommended to the CBK to aim to participate in the Fund's 2004 Coordinated Portfolio Investment Survey (CPIS) with a coverage limited to the financial sector. A follow-up mission in October 2005 reviewed progress in this area with the CBK.

\section{Data dissemination}

Kuwait is one of the first GDDS participants. Most of its metadata have not been updated in the Fund's DSBB since October 2002. The CBK has established its own webpage, which contains the following data that are made available online to the public: money and banking 
(monthly); balance of payments (annually); trade balance (monthly); exchange rate (average, monthly); GDP by sector and expenditure at current and constant prices (annually); public finance (selected data are available monthly); CPI and WPI (monthly with about a threemonth lag); and securities market indicators (quarterly). Similarly, the Ministry of Planning has constructed a webpage where the CSO, publishes data on national accounts, prices, and other related statistics. The Ministry of Finance's webpage includes elaborated data for the actual and estimated budget. In addition, the KIA's webpage provides data on stock market indices, volume and value of securities traded, as well as privatization schedules and other related information. 
KUWAIT: TABLE OF COMMON INDICATORS REQUIRED FOR SURVEILLANCE

(As OF FEBRUARY 2, 2006)

\begin{tabular}{|c|c|c|c|c|c|}
\hline & $\begin{array}{c}\text { Date of } \\
\text { latest } \\
\text { observation }\end{array}$ & $\begin{array}{l}\text { Date } \\
\text { received }\end{array}$ & $\begin{array}{c}\text { Frequency } \\
\text { of } \\
\text { Data }^{1}\end{array}$ & $\begin{array}{l}\text { Frequency } \\
\text { of } \\
\text { Reporting }\end{array}$ & $\begin{array}{l}\text { Frequency } \\
\text { of } \\
\text { publication }\end{array}$ \\
\hline Exchange Rates & $1 / 06$ & $2 / 06$ & M & M & M \\
\hline $\begin{array}{l}\text { International Reserve Assets and Reserve Liabilities } \\
\text { of the Monetary Authorities }{ }^{2}\end{array}$ & $12 / 05$ & $1 / 06$ & M & M & M \\
\hline Reserve/Base Money & $10 / 05$ & $12 / 05$ & M & M & M, Q \\
\hline Broad Money & $10 / 05$ & $12 / 05$ & M & M & M, Q \\
\hline Central Bank Balance Sheet & $10 / 05$ & $12 / 05$ & M & M & M, Q \\
\hline Consolidated Balance Sheet of the Banking System & $10 / 05$ & $12 / 05$ & M & M & M \\
\hline Interest Rates & $10 / 05$ & $12 / 05$ & M & M & M \\
\hline Consumer Price Index & $10 / 05$ & $12 / 05$ & M & M & M \\
\hline \multicolumn{6}{|l|}{$\begin{array}{l}\text { Revenue, Expenditure, Balance and Composition of } \\
\text { Financing - General Government }\end{array}$} \\
\hline $\begin{array}{l}\text { Revenue, Expenditure, Balance and Composition of } \\
\text { Financing-Central Government }{ }^{3}\end{array}$ & FY2003/04 & $12 / 04$ & $A^{4}$ & A & $\begin{array}{r}\text { Not } \\
\text { published } \\
\text { on Fund } \\
\text { standards }\end{array}$ \\
\hline $\begin{array}{l}\text { Stocks of Central Government and Central } \\
\text { Government-Guaranteed Debt }\end{array}$ & $09 / 05$ & $10 / 05$ & M & M & M \\
\hline External Current Account Balance & 2004 & $08 / 05$ & A & A & A \\
\hline Exports and Imports of Goods and Services & $06 / 05$ & $08 / 05$ & M & M & Q \\
\hline GDP/GNP & 2004 & $12 / 05$ & A & A & A \\
\hline Gross External Debt ${ }^{5}$ & 2003 & $12 / 04$ & A & A & A \\
\hline
\end{tabular}

${ }^{1}$ Daily (D), Weekly (W), Monthly (M), Quarterly (Q), Annually (A); NA: Not Available

${ }^{2}$ Central Bank of Kuwait only.

${ }^{3}$ Fiscal year data only.

${ }^{4}$ Higher frequency data available only in national format.

${ }^{5}$ Primarily private sector; except for a small volume of trade credits, Kuwait has no public external debt. 


\section{Statement by IMF Staff Representative \\ March 10, 2006}

This statement provides information on recent developments in Kuwait that has become available since the staff report was circulated to the Executive board on February 22, 2006. The new information does not change the thrust of the staff appraisal.

Fiscal developments. The 2006-07 budget framework was announced recently. The budget is based on an oil price assumption of $\$ 36$ per barrel compared with $\$ 21$ per barrel assumed in the 2005-06 budget, and the average export price of $\$ 47$ per barrel estimated to have been received in 2005/06. The total expenditure has been budgeted at KD 10.326 billion, an increase of almost 43 percent over the 2005/06 budget allocation of KD 7.232 billion. The increase is largely on account of KD 2.2 billion allocated to finance a part of the accumulated actuarial shortfall of the Public Institution for Social Security (KPISS). Excluding this transfer to the KPISS, the budget framework envisages an increase of 12.4 percent in total spending over the 2005/06 budget. The increase in wages and salaries (chapter I) is budgeted to be limited at 7.6 percent. However, the allocation for goods and services (chapter II), transport and equipment (chapter III), and capital spending including land acquisition (chapter IV) have been significantly increased from their 2005/06 budget allocations by 31.8 , 38.9, and 27.7 percent, respectively.

Oil sector developments. The oil ministry has resumed discussions with parliament over the proposed Project Kuwait bill relating to the development of the country's northern oil fields. Meanwhile, Kuwait has signed a joint-venture deal with China to build a petrochemical refining complex in China with an investment of over $\$ 6$ billion.

Monetary developments. The final quarter of 2005 showed a continuation of the trend observed during the first three quarters. Broad money grew by 16.5 percent during the year, mainly due to the dynamism of private sector credit (growing by 14.2 percent of the initial broad money stock). Growth of net foreign assets (NFA), however, decelerated substantially in the final quarter of the year, containing the 12-month growth in relation to broad money at 4.8 percent (down from 15.7 percent as of end-September). These developments are closely linked to the reintroduction of market-based monetary management mechanisms by the Central Bank of Kuwait (CBK), which encouraged banks to switch from foreign assets to CBK bonds and deposits. 
Stock market developments. Kuwait has been moderately resilient to the recent correction in stock prices in several GCC equity markets. After growing moderately vis-à-vis other major oil exporting countries in the GCC during 2004-05 (see Box 1 in the staff report SM/06/74, 2/22/06), the weighted Kuwaiti stock price index in the first two months of the year has remained virtually unchanged, despite a modest decline (4 percent) from its peak level in earlyDecember 2005.

\begin{tabular}{|c|c|c|c|}
\hline & Cumulative & Jan.-Feb. & Peak to \\
\hline & $2004-05$ & 2006 & Feb. 2006 \\
\hline Bahrain & 61.2 & 2.4 & -4.6 \\
\hline Kuwait Weighted & 93.0 & 0.4 & -4.2 \\
\hline Oman & 78.8 & 7.7 & -7.6 \\
\hline Qatar & 180.1 & -22.8 & -33.3 \\
\hline Saudi Arabia & 276.6 & 8.9 & -5.5 \\
\hline Abu Dhabi Securities Market (U.A.E.) & 296.1 & -13.4 & -27.8 \\
\hline Dubai Stock Market (U.A.E.) & 632.6 & -20.2 & -35.8 \\
\hline Shua'a Capital Index 2/ & 215.0 & 7.3 & -1.5 \\
\hline
\end{tabular}




\section{INTERNATIONAL MONETARY FUND}

\section{Public Information Notice}

Public Information Notice (PIN) No. 06/35 FOR IMMEDIATE RELEASE

March 29, 2006
International Monetary Fund $70019^{\text {th }}$ Street, NW

Washington, D. C. 20431 USA

\section{IMF Executive Board Concludes 2006 Article IV Consultation with Kuwait}

On March 10, 2006, the Executive Board of the International Monetary Fund (IMF) concluded the Article IV consultation with Kuwait. ${ }^{1}$

\section{Background}

Kuwait's macroeconomic performance strengthened further in 2004 and 2005. Real GDP expanded at an average rate of 7.5 percent, as a result of higher oil production and buoyant non-oil activity (6.4 percent). After taking into account the terms-of-trade gains, per capita GDP increased by 44 percent to more than $\$ 26,000$ during the two-year period through 2005. Inflation remained low at 1.3 percent in 2004, although it has risen to almost 4 percent in 2005, due to rising non-oil activity, abundant liquidity, and the delayed effect of the depreciation of the dinar against euro and yen. The weighted stock price index more than tripled during 2003-05, although the pace of increase over the recent two-year period (39 percent annually) has been slower than in other heavily oil-endowed Gulf Cooperation Council (GCC) countries, in part reflecting a tighter monetary policy stance.

The central government budgetary position strengthened further due to higher oil revenues, with the overall fiscal surplus estimated at 24 percent of GDP in 2004/05. Fiscal policy was expansionary in 2004/05, as expenditures increased by more than 14 percent and the non-oil primary deficit in relation to non-oil GDP increased by 4 percentage points to 61 percent.

\footnotetext{
${ }^{1}$ Under Article IV of the IMF's Articles of Agreement, the IMF holds bilateral discussions with members, usually every year. A staff team visits the country, collects economic and financial information, and discusses with officials the country's economic developments and policies. On return to headquarters, the staff prepares a report, which forms the basis for discussion by the Executive Board. At the conclusion of the discussion, the Managing Director, as Chairman of the Board, summarizes the views of Executive Directors, and this summary is transmitted to the country's authorities. This PIN summarizes the views of the Executive Board as expressed during the Executive Board discussion based on the staff report.
} 
The expansionary fiscal stance was primarily attributable to sharply higher subsidies and transfers and higher capital outlays, while the growth in the wage bill was moderate. Overall, two-thirds of the increase in hydrocarbon revenues is estimated to have been saved in 2004/05, and Kuwait's government saving rate of 28 percent of GDP in 2004/05 was the highest amongst all GCC countries.

Broad money growth steadily accelerated during 2004-05 and grew by 16.7 percent during the 12-month period through September 2005, despite efforts to tighten the stance of monetary policy. This acceleration is attributable to the expansion of credit to the private sector (13.1 percent of broad money) and an increase in net foreign assets (15.7 percent of broad money). A tightening of monetary conditions since the second half of 2004 was pursued by increasing the benchmark interest rate in line with global interest rate developments, by introducing a ceiling on the credit to deposits ratio in July 2004, and by the re-introduction of market-based monetary instruments in August 2005. Banking supervision has strengthened further, and Central Bank of Kuwait applied the Basel II capital adequacy requirements for conventional banks effective December 31, 2005. The banking sector has been opened further for foreign banks.

The external current account registered annual surpluses averaging $\$ 25$ billion (37 percent of GDP) during 2004-05, primarily on account of high oil revenues. At an annualized rate, exports of oil and oil products increased by over 47 percent, but non-oil export growth slowed down to 15 percent following a surge of about 70 percent in 2003 , because of slower growth of re-exports to Iraq. Import growth remained high as a result of strong domestic economic activity. The real effective exchange rate (REER) of the Kuwaiti dinar depreciated by 5 percent in 2004; however, with the strengthening of the U.S. dollar vis-à-vis other major currencies in recent months, the REER appreciated by 11.7 percent during January-November 2005.

Progress continues on the structural reform front, albeit at a slow pace. Private sector participation in the sectors previously dominated by the public sector has increased (particularly in telecommunications, airlines, and infrastructure development). However, several draft laws (including the privatization and competition laws) aimed at promoting a more market-friendly business environment are awaiting parliamentary approval. The Kuwaitization policy, in place since October 2003 and aimed at increasing the proportion of Kuwaitis employed in the private sector, is being applied in a flexible manner and contributed to a higher proportion of Kuwaiti nationals joining the private sector in recent years.

\section{Executive Board Assessment}

Executive Directors commended the authorities for a further strengthening of Kuwait's macroeconomic position in 2005. The high pace of economic expansion, driven in part by oilrelated inflows and terms-of-trade gains, boosted per capita income and contributed to large fiscal and current account surpluses as well as to the rapid accumulation of external assets for future generations. Looking ahead, Directors agreed that Kuwait's financial position is likely to remain strong over the medium term given the favorable outlook for oil prices. They encouraged the authorities to develop a comprehensive and transparent strategy to manage fiscal surpluses 
over the medium-term as well as to foster private-sector-led economic diversification, growth and job creation, which are needed to absorb the rapidly growing Kuwaiti labor force.

Directors commended the authorities for continuing to play a constructive role in support of oil price stability. As oil production is currently running almost at full capacity, they supported the large investment plans being implemented to expand capacity, increase refining operations, and almost double petrochemicals production. These actions demonstrated the authorities' readiness to support global economic expansion through oil market stability and also realize financial gains for the Kuwaiti population.

Directors observed that Kuwait's overall fiscal position will remain in comfortable surplus over the medium term, and urged the authorities to seize this opportunity to further improve the structure of the budget by gradually increasing capital expenditure, rationalizing subsidies, and achieving a better balance between productive expenditure and fiscal savings. They welcomed the authorities' commitment to contain recurrent outlays despite intensifying pressures for higher expenditures and new public sector hiring, while increasing spending on health, education, and physical infrastructure. Directors noted that efficient management of the rapidly growing public sector savings will be key to Kuwait's long-term fiscal viability. Directors supported the authorities' plan to build up the reserves of the Reserve Fund for Future Generations, and the recent budget announcement to use a part of the fiscal surplus to recapitalize the social security system, but also underscored the importance of implementing a reform program to ensure the social security system's long-term actuarial soundness. With regard to increasing non-oil revenues, some Directors suggested that consideration be given to the introduction of a Value Added Tax, in coordination with other members of the GCC.

Directors commended the authorities for their prudent conduct of monetary policy, which has helped maintain price stability and the exchange rate peg. They supported the authorities' intention to keep the exchange rate peg unchanged until the GCC monetary union is formed, and to remain open toward the choice of exchange rate regime under the planned monetary union. Directors observed that the ceiling on the loans-to-deposits ratio introduced in 2004 to tighten monetary conditions has contributed to a deceleration in the rate of credit growth in 2005 and to a rapid buildup of deposits. They suggested, however, that consideration be given to phasing out the ceiling on the loans-to-deposits ratio, in light of the diminished effectiveness of the ceiling and the reintroduction of market-based instruments.

Directors commended the authorities for ensuring that the Kuwaiti banking system is financially sound, well managed, and well supervised. They welcomed the steps taken to further strengthen banking supervision and open further the sector to foreign banks. Directors observed that the continuing upward trend in the stock price index in recent years, while reflecting strong economic fundamentals, should be carefully monitored to assess its potential impact on the financial sector. In this context, they urged the authorities to implement the Financial Sector Assessment Program recommendations relating to the stock market and insurance sector. Directors recommended, in particular, an expeditious passing of capital market and insurance laws, and establishing comprehensive oversight of the stock exchange, investment companies, and the insurance sector. Directors noted that, while the banking system appears to have the 
ability to withstand any reasonable market correction, there is scope for improved transparency through the implementation of more comprehensive accounting standards for other financial and non-financial companies. Regarding Anti-Money Laundering/Combating Financing of Terrorism, the authorities were encouraged to work toward adopting the legislation currently under review and to authorize the Financial Intelligence Unit to share information with its global counterparts.

Directors urged the authorities to cast structural reforms in the context of a comprehensive strategy aimed at strengthening the private sector, and increasing investment and employment. They encouraged the authorities to expedite the updating of outdated laws and regulations to promote a more market-friendly environment, and to move to market-based pricing of electricity, petroleum products, and water. To promote further private sector participation, a number of Directors also encouraged the authorities to reduce the maximum income tax rate on foreign companies, in line with other GCC countries. Directors urged the authorities to apply the Kuwaitization policy flexibly, so that the competitiveness and profitability of the private sector are not adversely affected, and to intensify their efforts to raise the skills of the Kuwaiti labor force. Directors also encouraged the authorities to consider positive incentive schemes in support of the goals of the Kuwaitization policy.

Directors welcomed the improvements in the quality of economic data. They urged the authorities to increase the timeliness and dissemination of some key economic data. Directors also encouraged the authorities to improve communications between the various government agencies to improve compilation of both the national income and balance of payments statistics. Directors also suggested that the authorities adopt common data standards, in coordination with other GCC countries, as a step toward establishing the convergence criteria for the planned monetary union. They welcomed Kuwait's contribution to oil market transparency by providing data to the Joint Oil Data Initiative, and urged the authorities to improve the timeliness of oil data provision.

Directors expressed their appreciation to the Kuwaiti authorities for their continued support to low-income countries through their sizeable external development assistance program, including through the Heavily Indebted Poor Countries Initiative.

Public Information Notices (PINs) form part of the IMF's efforts to promote transparency of the IMF's views and analysis of economic developments and policies. With the consent of the country (or countries) concerned, PINs are issued after Executive Board discussions of Article IV consultations with member countries, of its surveillance of developments at the regional level, of post-program monitoring, and of ex post assessments of member countries with longer-term program engagements. PINs are also issued after Executive Board discussions of general policy matters, unless otherwise decided by the Executive Board in a particular case. 


\section{Kuwait: Selected Economic Indicators}

\begin{tabular}{|c|c|c|c|c|c|}
\hline & 2000 & 2001 & 2002 & 2003 & 2004 \\
\hline & \multicolumn{5}{|c|}{ (Percent change) } \\
\hline \multicolumn{6}{|l|}{ Production and prices } \\
\hline Real GDP & 4.8 & 0.7 & 5.1 & 13.2 & 6.4 \\
\hline Real oil GDP & 2.2 & -3.3 & -7.9 & 19.8 & 7.7 \\
\hline Real non-oil GDP & 6.5 & 3.5 & 13.1 & 10.1 & 6.3 \\
\hline Consumer price index & 1.6 & 1.4 & 0.8 & 1.0 & 1.3 \\
\hline & \multicolumn{5}{|c|}{ (In percent of GDP; unless otherwise indicated) } \\
\hline \multicolumn{6}{|l|}{ Financial variables $1 /$} \\
\hline Total revenue, of which: & 78.3 & 60.7 & 59.8 & 55.2 & 59.6 \\
\hline Oil and gas & 54.2 & 41.4 & 45.3 & 42.6 & 46.0 \\
\hline Investment income & 19.8 & 12.7 & 9.6 & 8.1 & 9.9 \\
\hline Total expenditure & 38.5 & 43.9 & 40.3 & 37.8 & 35.2 \\
\hline Current & 35.4 & 39.3 & 35.6 & 33.1 & 30.7 \\
\hline Capital & 3.1 & 3.9 & 4.3 & 4.4 & 3.7 \\
\hline Overall fiscal balance & 39.9 & 16.8 & 19.5 & 17.4 & 24.4 \\
\hline Change in broad money supply (in percent) & 6.3 & 12.8 & 4.8 & 7.8 & 12.1 \\
\hline Interest rate (in percent) $2 /$ & 5.4 & 3.7 & 2.2 & 1.5 & 1.6 \\
\hline & \multicolumn{5}{|c|}{ (In millions of U.S. dollars; unless otherwise indicated) } \\
\hline \multicolumn{6}{|l|}{ External sector } \\
\hline Exports, of which: & 21,298 & 17,910 & 17,010 & 24,901 & 33,321 \\
\hline Crude oil and refined products & 18,182 & 14,977 & 14,057 & 19,567 & 27,764 \\
\hline Imports & $-11,369$ & $-12,406$ & $-13,958$ & $-16,464$ & $-19,848$ \\
\hline Current account balance (deficit $=-$ ) & 14,671 & 8,328 & 4,250 & 9,414 & 17,323 \\
\hline In percent of GDP & 38.9 & 23.9 & 11.2 & 20.4 & 31.1 \\
\hline Central Bank of Kuwait's international reserves 3/ & 6,577 & 9,268 & 8,455 & 6,744 & 7,451 \\
\hline In months of imports of goods and services & 7.6 & 9.7 & 8.0 & 5.6 & 5.1 \\
\hline Real effective exchange rate (percent change) & 4.2 & 5.2 & -0.9 & -7.9 & -5.2 \\
\hline
\end{tabular}

Sources: Data provided by the authorities; and IMF staff estimates.

1/ Fiscal year ending March 31.

2/ Three-month Kuwaiti dinar deposit rate.

3/ Excludes SDRs and IMF reserve position. 
This page intentionally left blank

(CInternational Monetary Fund. Not for Redistribution 


\section{Statement by Shakour Shaalan, Executive Director for Kuwait \\ March 10, 2006}

1. On behalf of the Kuwaiti authorities, we thank staff for a well-balanced set of reports, which evaluate Kuwait's policy options for consolidating macroeconomic stability, while providing a comprehensive review of strategies aimed at fostering medium- and long-term growth.

\section{Recent Developments}

2. Buoyant oil and non-oil activity over the past twelve months undeniably strengthened Kuwait's already solid macroeconomic performance further. This performance was coupled with subdued inflation, and exceptionally high fiscal and external surpluses. As a result, per capita GDP increased to more than US\$26,000, assets for future generations continued to buildup, and Kuwait consolidated its remarkably strong net external creditor position. At the same time, domestic private investment as a share of GDP increased markedly, equities continued to increase strongly, and unemployment remained low despite the growing labor force. Alongside favorable oil market developments, which have helped in entrenching Kuwait's strong performance, sound economic policies, as well as prudent management of hydrocarbon revenues over time have been major contributors.

3. Looking forward, the medium-term outlook for the Kuwait economy remains strong. This is due to the determination to maintain sound macroeconomic policies and a prudent investment policy of oil proceeds in external assets. These policies contributed largely to reducing Kuwait's vulnerability to international oil price volatility. The Kuwaiti authorities are determined to take advantage of the remarkable oil revenues induced windfall opportunity to launch reforms aimed at achieving sustainable high rates of GDP growth in the medium- and long-term. These include efforts aimed at productively diversifying the economy, reforming the labor market to encourage private sector employment and reduce the role of the public sector, achieving long-term fiscal consolidation, and providing an enabling environment for private sector-led growth.

\section{Supporting Oil Price Stability}

4. Kuwait is well aware of its responsibilities as a major global oil producer, with about 8 percent of the world's proven crude oil reserves. It continued to play a constructive role in ensuring an additional supply of oil over the past years, thus supporting international oil price stability. The authorities have raised their production of crude oil by 47.5 percent since 2002 in response to the increasing global demand and are currently running almost at full capacity.

5. The authorities' readiness to support global oil market stability is reflected by launching a mega investment program of US\$22 billion for expanding crude oil capacity, increasing refining capacity, almost doubling the production of petrochemical products, and boosting gas production for domestic uses. The project would be essentially financed by the Kuwait Petroleum Corporation's own resources and its joint venture foreign partners. 


\section{Fiscal Developments and Policies}

6. Higher oil revenues have led to a significant strengthening of the fiscal position over the past two years, with the overall fiscal surplus estimated at 24 percent of GDP in 2004/05. In spite of increasing demands on the budget engendered by the favorable fiscal position-already manifested in higher subsidies and transfers-the authorities remain committed to fiscal prudence. This is evidenced in the steady decline, expected to continue into the future, in both current and total expenditures in relation to GDP, from 39.3 percent and 43.9 percent in $2001 / 2002$ to 30.7 percent and 35.2 percent, respectively, in 2004/05. The composition of spending has also improved with the share of wages and salaries as well as subsidies and transfers in total expenditures declining over the same period. The prudent fiscal stance has allowed the government to accumulate substantial foreign assets, with two-thirds of the increase in hydrocarbon revenues estimated to have been saved in 2004/05.

7. The fiscal position is expected to remain exceptionally strong in the medium term. Nonetheless, the authorities remain committed on using the surplus in a manner consistent with ensuring fiscal sustainability in the medium term and intergenerational equity. To improve intergenerational equity, the Reserve Fund for Future Generations will likely continue to receive an additional contribution amounting to 5 percent of government revenues - in addition to the statutory annual transfer of 10 percent of all government revenues-provided the budget outcome remains favorable. A portion of the remaining surplus will be also utilized to increase investments in health and education and to improve physical infrastructure, within the medium-term fiscal framework expenditure program. It is worth noting that the sizable planned budget outlays are in line with Kuwait's increasing absorption and implementation capacity. On the other hand, the authorities would like to reiterate their commitment to moderate increases in the general level of wages in the economy and to stricter rules for additional recruitment in the public sector.

8. Going forward, the focus on improving the structure of the budget and expenditure management will be maintained. The authorities recognize that there is scope for rationalizing transfers and subsidies, recapitalizing the social security system, and achieving a better balance between productive expenditure and fiscal savings. They are considering the staff recommendations in this regard. The authorities are also intent on implementing planned budgetary reforms, which are now included in the five-year plan. These reforms include the introduction of a three-year rolling budget, the consolidation of the budgetary process, and the adoption of budget classifications in line with international accounting standards. Efforts are also continuing to coordinate with other GCC members the introduction of a Value Added Tax.

\section{Monetary and Financial Sector}

9. The Central Bank of Kuwait (CBK) was successful in maintaining price and exchange rate stability through continued monetary restraint. In order to ensure that money and credit growth remains commensurate with the expansion of non-oil activity, the CBK increased the benchmark interest rate in line with global interest rate developments, introduced a ceiling on the credit to deposit ratio, and recently relied upon market-based 
monetary control mechanisms. These policies have resulted in a substantial increase in domestic currency deposit rates, which have risen above U.S. dollar deposit rates. Moreover, the rate of credit growth was restrained in 2004-05, which in turn contributed to moderating equity price increase, while restoring the balance between the rate of growth of credit and deposits. The authorities consider the loan-to-deposit ratio ceiling as a temporary prudential measure aimed at avoiding any emergence of credit risk that could undermine the soundness of the banking sector. Although they do not believe that the measure has interfered with the efficient allocation of bank resources, the authorities will continue to closely monitor the situation, as all local banks have met the loan-to-deposit ratio requirement and are now, with their increasing deposit base, in a position to meet the private sector financing needs.

10. The financial sector strengthened further in 2005 and played an important role in supporting non-oil private sector activity. The Kuwaiti banking system realized strong profits and considerably increased provisions coverage for non-performing loans. Banking supervision has strengthened further over the past year, foreign competition was allowed in the banking sector, in line with the recent amendment of the banking law, and the CBK applied the Basel II capital adequacy requirements for conventional banks effective December 31, 2005. The CBK is confident that these developments will further strengthen the soundness and stability of the banking system by motivating banks to apply best practices in managing and monitoring various aspects of risk. While there are clear indications that the banking system is increasingly resilient to any reasonable stock market correction, the authorities are monitoring the upward trend in the stock market index closely. In this context, accelerating the approval of the stock market and insurance sector laws, as recommended by staff, in addition to improving the banking sector transparency, remain a priority.

\section{External Sector}

11. The external current account surplus rose substantially in 2004-05 mainly due to higher oil export receipts, as non-oil exports which increased strongly in 2003, were slower on account of a decline in re-exports to Iraq. Imports remained high, on account of the strong domestic economic activity. Staff's projections indicate that a substantial external current account surpluses will continue over the medium term. Although they take comfort from these projections, the Kuwaiti authorities will maintain their efforts to diversify the production and export base in an effort to reduce the economy's vulnerability to developments in international oil markets. Several measures, aimed at allowing market access and competition in industries previously dominated by the public sector, including the telecommunications, airlines, and infrastructure sectors, were implemented. These measures included granting licenses for three airlines and four additional private universities, allowing private companies to operate gas stations, building two new power plants, completing the joint venture Boubiyan Island port project by 2008, in addition to the proposed North-South GCC train line.

12. Significant progress has been made in trade liberalization and regional integration. The GCC common external tariff at 5 percent has been in effect since early 2003, and import duties are no longer levied on products from Arab countries under the Greater Arab Free Trade Area since January 2005. Moreover, the GCC common market is projected to come 
into effect in 2007 and the GCC countries have agreed to negotiate free trade agreements (FTAs) with other countries or regions collectively in the future, while an FTA with the European Union is expected to be signed later this year. Being a WTO member for over ten years, Kuwait remains committed to further opening and liberalizing its economy. In this context, the foreign direct investment law of 2003 is about to be amended in line with international best practices, in an effort to attract foreign investment.

\section{Other Structural Reforms}

13. In order to promote a more business-friendly environment, the government is considering amending the tax law aimed at reducing the corporate income tax from 55 to 25 percent on foreign business. The privatization law also awaits parliamentary approval and the authorities remain committed to advance a comprehensive strategy for government divesture from major state-owned enterprises. The authorities also plan to legislate the Competition Law and to implement a legal framework for large projects under the public-private partnerships program.

14. The Kuwaiti authorities acknowledge that sustaining vigorous rates of growth in the medium and long term requires a flexible implementation of the Kuwaitization program, with due consideration to safeguarding the competitiveness of the private sector. They remain committed to moderate increases in wages and to stricter rules for additional recruitment in the public sector. This, together with the program aimed at providing vocational training, job search allowances for the unemployed, and enhancing job placement services, will encourage Kuwaiti nationals to improve their skills to be able to compete for job opportunities in the private sector.

\section{Statistical Issues}

15. Considerable progress has been made in improving the quality and dissemination of economic data, especially with regard to the timely provision of the CPI and WPI. Kuwait is also a strong supporter of the Joint Oil Data Initiative to help improve oil data transparency. In addition to the planned investment survey aimed at better assessing non-financial foreign direct investment, the authorities intend to subscribe to the Fund's Special Data Dissemination System. Notwithstanding this progress, the Kuwaiti authorities remain strongly committed to further improvements in data collection and dissemination, in line with best practices. 